\title{
REGULATING THE DIGITAL CITY: THE PLANNING CHALLENGES OF AIRBNB
}

\author{
by \\ Corinna Prior \\ Master of History, Carleton University, 2009 \\ Bachelor of History, Carleton University, 2007
}

\author{
A Major Research Paper \\ Presented to Ryerson University \\ in partial fulfillment of the requirements for the degree of \\ Master of Planning \\ in \\ Urban Development
}

Toronto, Ontario, Canada, 2017

(C) Corinna Prior 2017 


\section{Author's Declaration for Electronic Submission of a MRP}

I hereby declare that I am the sole author of this major research paper. This is a true copy of the major research paper, including any required final revisions.

I authorize Ryerson University to lend this major research paper to other institutions or individuals for the purpose of scholarly research.

I further authorize Ryerson University to reproduce this major research paper by photocopying or by other means, in total or in part, at the request of other institutions or individuals for the purpose of scholarly research.

I understand that my major research paper may be made electronically available to the public. 


\title{
REGULATING THE DIGITAL CITY: THE PLANNING CHALLENGES OF AIRBNB
}

\author{
(C) Corinna Prior, 2017 \\ Master of Planning \\ in \\ Urban Development \\ Ryerson University
}

\begin{abstract}
This research paper investigates the impact that digital technological platforms are having on municipalities and the ways in which these practices can and are be incorporated into planning studies and regulatory frameworks. It uses the expansion of the short-term rental market as a case study, looking specifically at the Airbnb platform and its growth within the City of Toronto since 2011. Findings from the study indicate that municipalities need to explore the use of new digital tools like web scraping and advocating for APIs which allow for better data collection. Furthermore, the collection of data for municipal governance purposes is a practice that needs to be more clearly defined by either the provincial or federal governments. Interviews with key informants also suggest that there is a need to establish strong data agreement policies and to expand Information Technology departments to better equip municipalities to cope with technological change.
\end{abstract}

Keywords: digital platform, short-term rental, Toronto 


\section{Acknowledgements}

The completion of this major research paper would not have been possible without the support and guidance of my supervisor, Dr. Pamela Robinson, who first introduced me to the topic of urban informality and the plethora of ways in which digital technologies are impacting municipalities. From her insights into how government might use technology to her grounded academic research on the need for more data and the creative use of it, her ideas profoundly influenced my research. Her critique of the paper profoundly improved the analysis.

I would also like to thank my second reader, Dr. Jaclene Begley, whose critical eye and insight into the the housing market and into the ways in which data might be used to better understand it was greatly appreciated.

Although they cannot be named directly in these acknowledgements, my research paper could not have been completed without the assistance and patience of my four key informants. I am very thankful for the time they spent discussing planning and regulation issues surrounding short-term rentals and for the broader conversations we had about the ways in which technology is impacting their practice.

Finally, I would like to thank my family for their unwavering support throughout the process of completing this program. I owe a debt of gratitude especially to my partner, Abraham, who was always willing to listen to my ideas while washing too many dishes. I also could not have completed this work without the assistance and humour of my mother, who often provided late-night art direction and support, and to my sister, Kayla, who was always there to lend emotional support. 


\section{Table of Contents}

Introduction .......................................................................................................................................................... 1

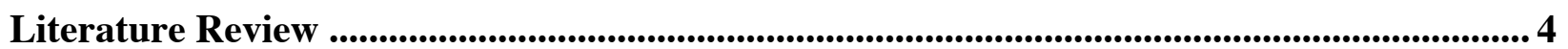

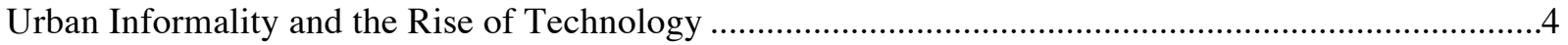

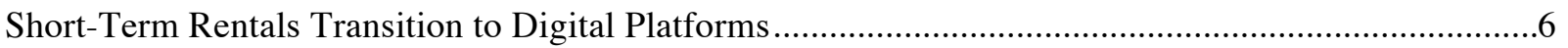

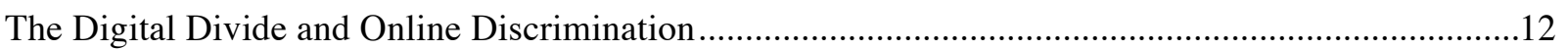

Access to Data and Issues of Privatized Enforcement ..........................................................................14

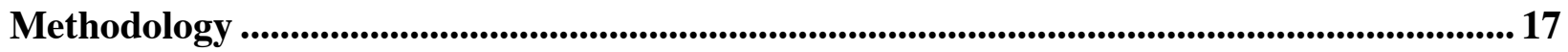

Different Regulatory Approaches to Short-Term Rentals .................................................... 19

The History of Residential Short-Term Rentals in Toronto .............................................................19

Three Different Approaches to Short-Term Rental Regulation...........................................................22

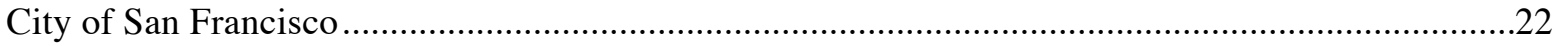

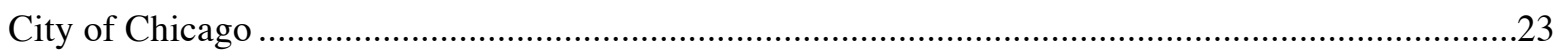

Province of Quebec

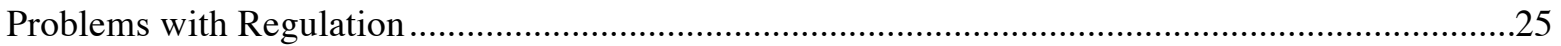

Avenues for Future Regulation of Short-Term Rentals in Toronto ....................................................26

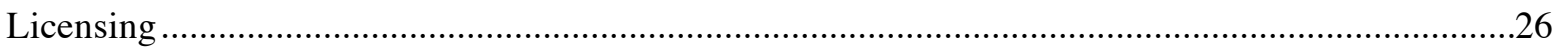

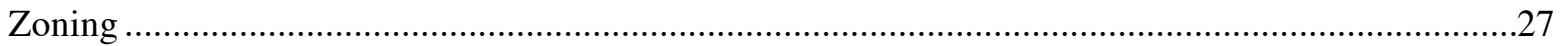

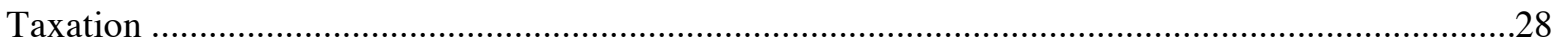

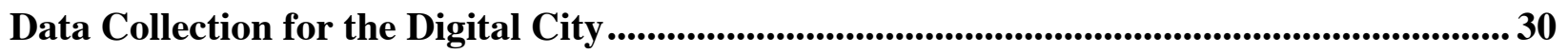

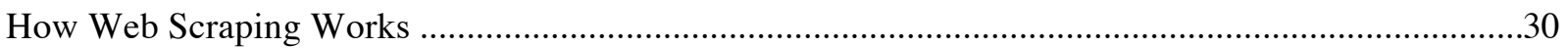

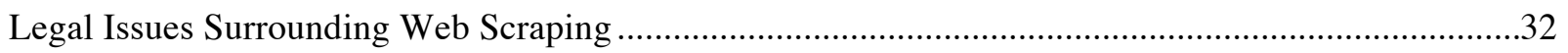

Web Scraping and Short-Term Rental Trends in Toronto .................................................................35

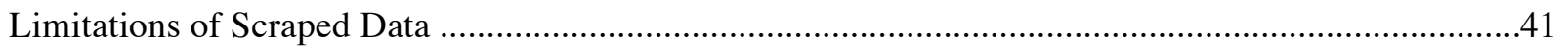

Municipal Approaches to the Regulation of Digital Platforms ............................................... 43

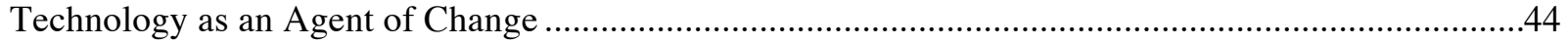

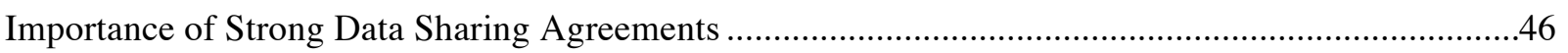

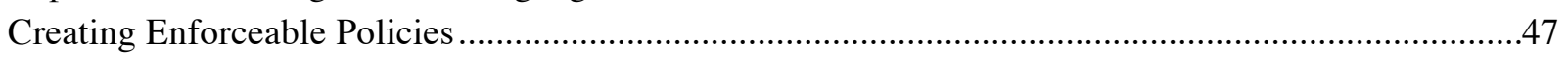

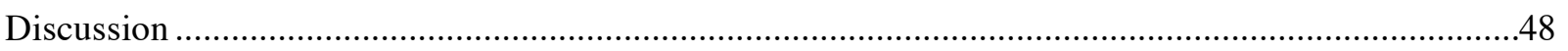

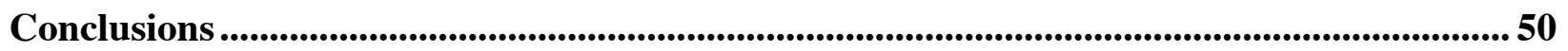

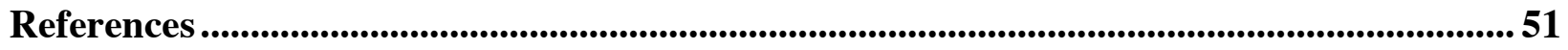




\section{List of Figures}

Figure 1: Percentage of room types listed on Airbnb by municipality (2016) ......................... 8

Figure 2: Chart showing the growth of total listings on the Airbnb platform. .......................... 9

Figure 3: Screenshot from the Airbnb Super Bowl 2017 televised commercial ....................... 14

Figure 4: Screenshot the distribution of Airbnb listings in the City of Vancouver ................... 15

Figure 5: Map showing the density of Airbnb listings throughout the City of Toronto............... 36

Figure 6: Map showing the highest rates of change throughout the City of Toronto.................. 37

Figure 7: Map showing the distribution of Airbnb listings throughout the City of Toronto ........ 38

Figure 8: Map showing the distribution of listings under the average monthly rental price....... 40 


\section{Introduction}

Uber, the world's largest taxi company, owns no vehicles. Facebook, the world's most popular media owner, creates no content. Alibaba, the most valuable retailer, has no inventory. And Airbnb, the world's largest accommodation provider, owns no real estate. (Goodwin, 2015)

The development and expansion of new technologies has created a digital dimension to cities that does not fit easily into municipal regulatory frameworks. Existing municipal policies and bylaws are designed to work within a physical city, where land can be divided into individually owned properties and regulated in terms of use. Digital technologies, in contrast, confuse these traditional structures by crossing boundaries and often introducing more complex and less concrete uses of space. Cities have become digitally enabled environments and this technological dimension is folded into and interacts with physical places in the city, yet it is often less visible to municipal regulators (MaRS Solutions Lab, 2016, 14; Castells, 2001, 86).

Municipal governments have begun to recognize the power and value in adopting open government policies and the ways in which publishing public data can redefine the relationships between governments and citizens (Robinson and Johnson, 2016, 65; Gray and Lämmerhirt, 2017, 2). As new technologies have emerged in the twenty-first century, however, private companies have also begun to create, collect, and use proprietary data to transform industries and the manner in which citizens interact with each other and their surroundings (Interian, 2016, 131; Motala, 2016, 469). Emerging from this technological-driven change are questions surrounding the role that municipal governments ought to have in regulating new international digital platforms operating within their cities. For example, how might governments regulate and enforce policies surrounding Uber cars or Airbnb rental units when both are largely invisible to a person standing on a physical street? How can governments monitor or effectively tax business transactions that occur on street corners? 
Currently, the rapid development of these digital technologies and platforms has led traditional municipal governments to adopt reactionary "whack-a-mole" approaches to individual technological phenomena, where policymakers attempt to regulate new technological platforms as they arise (Johal and Zon, 2015, 19). This method is problematic in the manner that it is reactionary, does not foster the development of holistic policies, and requires the coordination of City staff from different departments and different levels of government to regulate digital phenomena that defy easy categorization with limited access to data (Johal and Zon, 2015, 16). Yet there are commonalities in the ways that different technological platforms impact cities in the manner that they often promote the sharing of underutilized assets on a scale that was previously unimaginable (MaRS Solutions Lab, 2016, 11; Interian, 2016, 129). In this way, digital platforms can enable a physical property to serve multiple uses, transitioning from private homes to hotels, restaurants, places of business, or community spaces seamlessly as owners or renters have the opportunity and inclination. Spaces become more flexible than they once were as powerful digital technology connects those with access to property to other people in need.

The purpose of this research paper is to investigate the ways in which digital technologies are challenging the regulatory planning framework that exists in municipalities, concentrating specifically on the impact it has had within Toronto, Canada. In particular, I focus upon the issue of short-term rentals offered through Airbnb, a platform that connects "hosts" who have available space with potential "guests" looking for temporary accommodation. This digital platform has experienced rapid growth over the past five years, and there are now over 3 million listings worldwide and 12,000 within the City of Toronto alone (Airbnb, 2017; InsideAirbnb, 2017). From a planning perspective, one of the core challenges is the fact that these units are 
drawn from the preexisting residential stock, potential changing the use of these properties and replacing long-term housing with short-term rental accommodation.

In order to explore this issue, I will first conduct a literature review examining the history of informal short-term accommodation and its transition to a much broader digital network. I will then conduct a jurisdictional scan of three government bodies that have already grappled with the challenges of regulating Airbnb: San Francisco, Chicago, and the province of Quebec. The following section provides an examination of the type of data that can be acquired through webscraping and a discussion of the impact that this data suggests Airbnb is having on the City of Toronto. My final section presents findings from a series of interview held with municipal staff, discussing current approaches to regulating new technologies such as Airbnb.

As new technologies continue to emerge that alter the ways in which people navigate through, consume, live, and work within cities, municipal planners and bylaw enforcement staff must find ways to develop regulatory frameworks that have the flexibility to address these issues. Attempting to regulate each technology individually as it emerges within the existing regulatory framework will always present challenges as it predates powerful new communication tools and peer-to-peer networks. An alternative way forward would be to look holistically and the ways in which digital platforms and technologies are impacting the city, and to attempt to find new ways of governing the digital cities of the twenty-first century. Starting to find news ways of studying the city, gathering data, engaging with citizens, and recognizing the common threads that digital technologies present is paramount to this transition. 


\section{Literature Review}

Discussions of the rise of new digital platforms like Airbnb rarely emphasize the fact that informal short-term rentals have existed in urban spaces since the industrial revolution and that the idea of utilizing underused space to earn a profit is by no means new. What has changed is the scale upon which short-term rentals occur, the broad reach of the platform in all urban areas, and the ease with which it listings can be set up and advertised. Understanding the ways in which urban informality have shifted with the introduction of new technology, the specific transition of short-term rentals onto digital platforms, and the impact that this large-scale movement has had on users and municipalities is key to understanding trends in urban digital phenomena.

\section{Urban Informality and the Rise of Technology}

Technology is not often discussed in the context of urban informality, but a closer examination of the ways in which digital platforms are built up, spread, and used throughout cities suggests that the two topics are intertwined. Academic literature on informality arose largely in response to the migration of rural migrants into cities throughout various industrial revolutions, particularly in the developing world, and concentrated on informally built communities constructed to house them (Wegmann, 2014, 13). More recently, academics have begun to acknowledge that informality is a diverse subject that operates in cities all around the globe. Within an American context, Mukhija and Loukaitou-Sideris (2014) emphasize that informal practices can range from contexts as diverse as the unlicensed selling ice cream on a beach, to the unpermitted conversion of a garage into an apartment. 
While planners and policymakers might interpret these activities as unorganized, elicit, marginal, or even unlawful, these trends can overlook the fact that informal practices are often linked to formal economies and engage more deeply with questions surrounding citizens' right to the city (Roy, 2005, 155). Informal practices are necessarily products of state regulation, as it is the intervention of government which designates certain activities formal and simultaneously renders others informal. Within a Canadian context, municipal governments enforce traditional models of private property ownership above those of collective access to urban space (Roy, 2005, 148 and 156). While property law restricts communal access to urban land, land use regulations further restrict the types of ways in which private property might be used. Through this process, activities such as the informal occupation or the unsanctioned uses of land are interpreted as illegal actions. Further, these informal activities are often assumed to be the exception to the norm, occurring either illegally or due to oversights in the regulatory framework that require municipal attention (Mukhija and Loukaitou-Sideris, 2014, 298).

Yet, academics have recently concluded that informal activities are not the transitory result of an oversight in regulatory policies, but rather are pervasive and omnipresent activities that exist in all urban contexts and sometimes cannot be adequately addressed through legalization or regulation (Mukhiija and Loukaitou-Sideris, 2014, 298; Wegmann, 2014, 13; Mendez and Quastel, 2016, 1156). Structuralist arguments tend to point to the inequalities associated with the capitalist system of land ownership and emphasize that informal activities are the result of disenfranchised populations attempting to generate additional income (Castells and Portes, 1989, 12). Other neoliberal scholars interpret informal activities as resistance against the over bureaucracy of government (De Soto, 1989, 14). Finally, a third group of scholars sees an active role for government in supporting informal activities through more progressive policies or 
else structural changes in governance and law (Mukhija and Loukaitou-Sideris, 2014, 7; MaRS Solutions Lab, 2016, 9).

Before the expansion of digital networks, the scale of informal activities was limited in terms of its reach and physical location. Informal markets existed, but the ability of a seller to reach a buyer was hampered by that individual's immediate surroundings and audience. New technological platforms like Airbnb and Uber have expanded the scope of informal activities and made them harder to regulate by making them more accessible to a wider range of people. These peer-to-peer networks have transitioned otherwise small-scale informal activities into larger, more mainstream practices that challenge traditional industries. Donald Shoup (2014) provides one example where informal off-street parking around athletic events transitioned into several digital platforms such as ParkAtMyHouse and Parking Panda which allow users to sell private parking space online to those in need of off-street parking (280). Whereas individuals used to stand outside their properties with signs advertising parking at popular events, now any individual can list their private parking space through the platform and can find potential customers any time. Financial transactions are handled by the digital platform, so that no physical exchange of money ever need take place. Aside from the fact that different cars might be parked on the same driveway daily, this type of informal activity remains largely invisible as no signage need be put up in order to identify the spot.

\section{Short-Term Rentals Transition to Digital Platforms}

The transition to the digital provision of short-term rental accommodation began in the early 2000s through peer-to-peer networking. The first platform offering short-term accommodation that rose to significant prominence was CouchSurfing, which was launched in 
2003 by a developer who was travelling in Reykjavik and tried contacting students at the University of Iceland to find a couch to crash on for free (Molz, 2012, 32). After receiving over one hundred offers in twenty-four hours, the viability and potential of a platform designed to connect travelers with hosts became apparent. The CouchSurfing website had acquired 90,000 members by 2006, and in 2012 was the largest online hospitality network with over three million members registered on the platform (Molz, 2012, 32; Rosen et al., 2011, 983). The couch in CouchSurfing was a metaphor for many different types of hospitality that might be arranged through the website, including a literal couch, a private room, or even access to a completely separate apartment or guest house (Molz, 2012, 33). Other hosts did not offer accommodation, but might meet the traveler and show them around the city.

There are many similarities that exist between CouchSurfing and the other platforms that were to emerge later in the decade, particularly Airbnb. First, the website was set up to mimic social networking sites, through the creation of host and guest profiles including user pictures, a description of personal interests, and a messaging system to facilitate interaction. Further, the ways in which trust is established on the site are similar, through links to actual social media pages and references from other users. The main difference between CouchSurfing and platforms that were to emerge later on was that CouchSurfing was based on the principle of a free exchange in the sense that no money was to be paid for the accommodation or interaction. Instead, hosts and guests exchanged gifts, like preparing or taking a host out to dinner or reciprocating by opening up their own home to the host in turn. The community was adamant about not charging for accommodation and it became the philosophy of the platform which remained a not-for-profit organization until 2011, when it was sold to another company and radically changed its structure (Gallagher, 2012). 
Today, Airbnb has surpassed CouchSurfing as the most prominently used short-term accommodation platform. The platform has undergone significant growth in the past five years, particularly in urban areas. The company began in 2007 and has a similar conception story to that of the CouchSurfing developer, when two co-founders decided to offer affordable accommodation space in their apartment during a design industry conference in order to help pay for their expensive San Francisco rent (Slee, 2015, 30). Having received many requests from conference attendees, they began to consider the viability of offering underused space in their home to guests on a more regular basis. The principle difference between Airbnb and CouchSurfing is that Airbnb is a for-profit company and hosts charge guests for accommodation provision, although the amount charged is set by the host. As a result, the range in price varies greatly between different units and some of the spaces which can be rented are quite unique.

The types of listings offered on Airbnb are categorized on the basis of their levels of privacy, including entirely private units, private

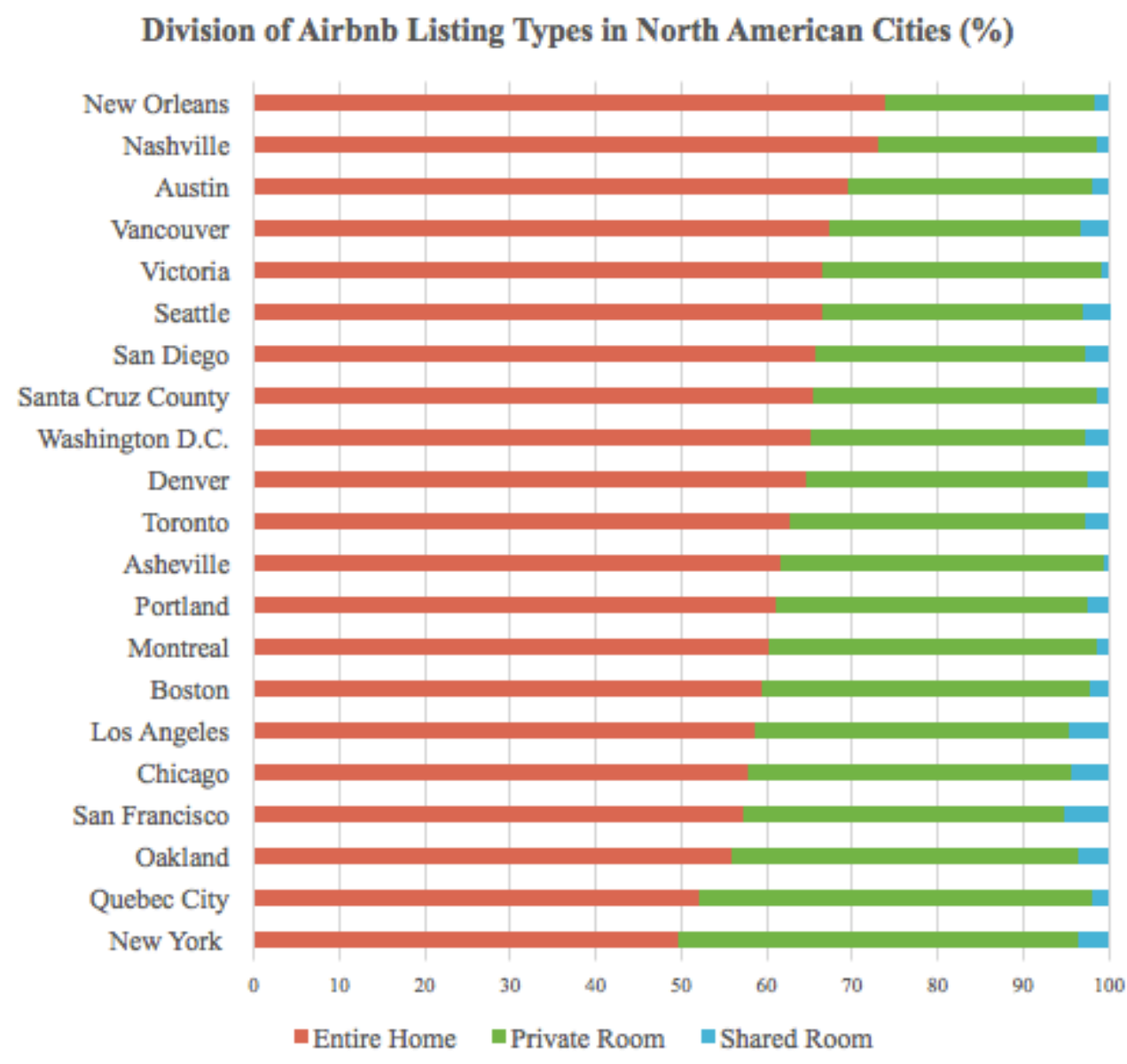

Figure 1: Percentage of room types listed on Airbnb by municipality (2016). Data retrieved from InsideAirbnb. 
rooms, and shared rooms. Entire apartments function as complete separate units, with private entryways and their own kitchen and bathroom facilities. Private rooms, in contrast, are separate bedrooms offered in a shared apartment with shared common areas. Shared rooms are the least private option and are generally a bed in a shared room with shared common areas. Although the specific breakdown of listing types varies by city, looking at data gathered by InsideAirbnb, the trend in North America cities is that roughly two-thirds (62.5\%) of all listings are entire units, while one third (34.9\%) are private rooms, and only a small portion (2.6\%) are shared rooms (see Figure 1).

In terms of the growth, Airbnb had 50,000 listings in 2011 mainly based in the United States and in Europe, however, most recent figures from February 2017 indicate that number has swelled to over 3 million

across 191 countries

Airbnb Total Listing Growth (2011-2017)

(Airbnb, 2017; Slee,

2015, 30; see Figure 2).

Since 2013, the growth

rate of listings offered

through the platform has

increased $90 \%$ annually

on average and has

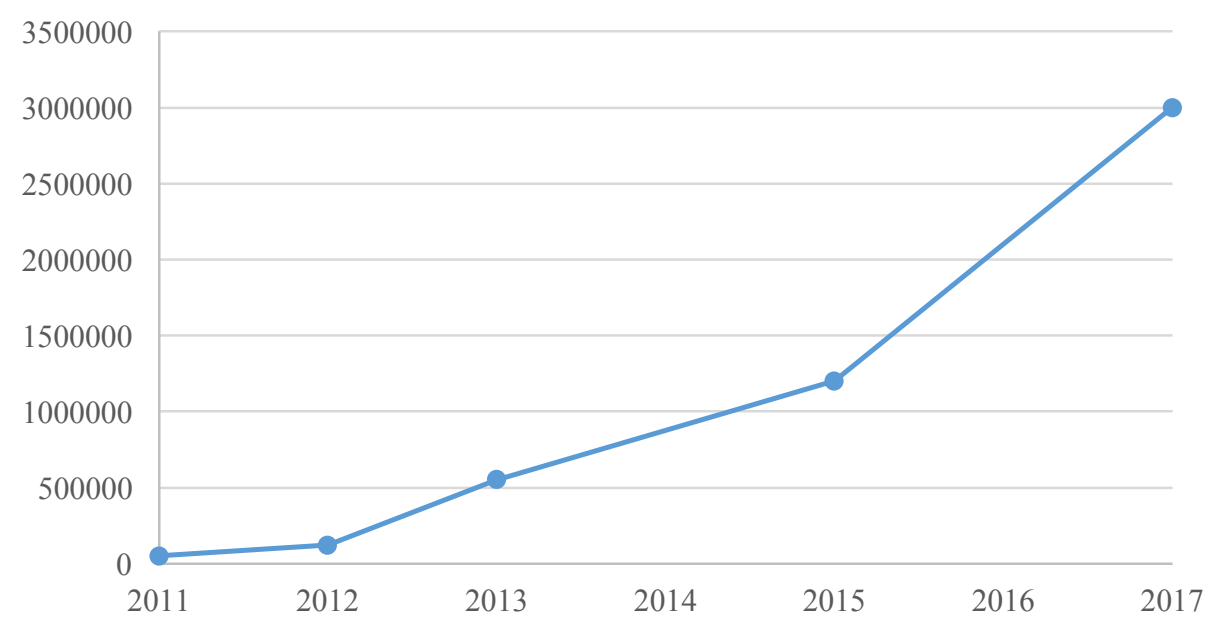

Figure 2: Chart showing the growth of total listings on the Airbnb platform.

particularly increased since 2015, when it became a more pronounced topic among municipal regulators.

In response to municipal concerns about some of the negative impacts the platform may be having on affordable housing and the long-term rental market, Airbnb recently released a 
national Policy Tool Chest to advocate for the benefits the platform provides. The company forcefully markets itself as an economically empowering platform that is "of the people, by the people and for the people," that "democratizes tourism" by spreading short-term accommodation more evenly throughout cities without altering neighbourhood character (Airbnb, Policy Tool Chest, 2016, 1 and 5). Based on survey data collected from users of the platform, Airbnb boasts that their platform allows $31 \%$ of travelers to take longer vacations due to lower accommodation costs, and provides needed funds to help homeowners and renters alike pay for rising housing costs.

More locally, Airbnb has begun campaigns to construct a case for the positive economic and housing impact of the company by hiring independent firms to investigate the local markets of certain major cities in which Airbnb has significant listings. The economic statement for the Toronto area, for example, emphasizes that Airbnb guests contributed \$292 million to the municipal economy in 2016, supporting nearly 6,000 full-time employment positions (Urban Metrics, 2017, 1). The Toronto housing policy statement reports that Airbnb entire home listings represent only $.85 \%$ of the city's total housing units and that these listings are only offered occasionally throughout the year with $46 \%$ of listings offering fewer than 30 nights, and nearly 90\% fewer than 180 nights (Airbnb, Housing and the City of Toronto, 2016, 2 and 7). Typical annual income for Airbnb hosts within the city were $\$ 5,330$, or $\$ 450$ per month which nearly $40 \%$ of all hosts rely on to help make ends meet—specifically paying for their own housing costs and utilities (Urban Metrics, 2017, 4). The report also makes a case for the platform assisting vulnerable populations in transition, suggesting that short-term accommodations can provide time to adjust to life in a new city, start a new career, or help someone through difficult medical situations (Urban Metrics, 2017, 3). In other words, Airbnb argues that it helps homeowners 
with rising housing costs, contributes greatly to local economies by bringing tourist dollars to new neighbourhoods, and provides flexible housing to those in need of short-term accommodation.

One of the core problems for city regulators, however, is that all data collected by Airbnb is proprietary and only the company itself has access to raw figures. This makes it extremely difficult for cities to study the impact of the platform, and some critics of the company have suggested that the data released by Airbnb is carefully selected to show the company in a positive light. Tom Slee (2015) notes that in the case of New York City, Airbnb reported that $87 \%$ of hosts using the site only have a single listing available, supporting the company's narrative that short-term accommodation assists residents coping with high housing costs allowing them to list underused space within their own homes. What Airbnb failed to mention is that the $13 \%$ of hosts with more than one listing actually make up $40 \%$ of the total listings throughout the city and account for $43 \%$ of all Airbnb visits to New York City (37). Slee was able to approximate this figure by scraping the Airbnb website for data — using a python code to pull geocoded information off the public website for subsequent analysis. Another report by the Attorney General's office in New York confirms Slee's estimate using data that Airbnb themselves provided after being subpoenaed, finding that $6 \%$ of hosts with more than two listings made up 36\% of Airbnb's revenue in the city (Schneiderman, 2014, 2; Slee, 2015, 38).

This type of discrepancy indicates the importance of finding new ways for government to access proprietary data from digital platforms operating throughout their cities. It is not sufficient to rely upon the published data of the company itself, which has a vested interest in presenting narratives that support their for-profit business ventures. Further, the accountability of the data needs to be measured in order to ensure that cities have the tools necessary to 
understand the impact of the platform and to use the information to inform future studies and regulations.

\section{The Digital Divide and Online Discrimination}

A consequence of the fact that digital platforms have developed so rapidly is that the inequities introduced through this medium are often overlooked by municipal regulators intent on trying to grapple with basic questions about how the technology fits into their regulatory framework. Academic discussions about the digital divide have begun to interrogate more deeply questions about access and barriers to internet-based technologies among different sociodemographic lines. Robinson et al. (2015) argue that "as the internet matures, forms of digital exclusion proliferate" both in regards to basic access to technology and the internet, as well as in terms of knowledge and skill (570). Further, issues of digital inequality interact intersectionally with racial, class, gender, and other axes of inequality (Robinson et al., 2015, 570). This potential for online inequality is another reason for government to observe digital technologies closely and produce policies that address both online and offline forms of discrimination.

Questions surrounding digital discrimination have lately come to light in the context of the Airbnb platform, where several studies have suggested that the online platform operates differently from ordinary hotel business models (Gumbs, Dodds, and Griffin, 2016, 24; Botsman and Rogers, 2010). Due to the fact that transactions through Airbnb occur in a digital environment, much emphasis is placed on establishing trust in both hosts and guests through the development of personal profiles which display pictures of the user, the listing, and which link to social media accounts like Facebook, LinkedIn, and Twitter (Gumbs, Dodds, and Griffin, 2016, 24; Edelman and Luca, 2014, 3). Hosts also have the ability to screen potential guests before 
accepting their requests for reservations, creating opportunity for discrimination on the basis of personal profiles.

Edelman, Luca, and Svirsky (2016) examined data from Airbnb listings in Baltimore, Dallas, Los Angeles, St. Louis, and Washington, D.C., in 2015, as well as data from an earlier paper on New York City in 2014 (Edelman and Luca, 2014). Their findings suggest that racial discrimination is prominent on the platform, with non-black hosts earning $12 \%$ more than African American hosts on average (Edelman and Luca, 2014, 4). This discrepancy is likely due to the fact that non-African-American hosts were able to charge 30\% higher rents than AfricanAmerican hosts and received more requests for reservations (Edelman and Luca, 2014, 9). Further, guests with Caucasian-sounding names were accepted by hosts $8 \%$ more often than those with African-American-sounding names (Edelman, Luca, and Svirsky, 2016, 8). AfricanAmerican names with the positive responses (Tamika, Darnell, and Rasheed) received fewer positive responses than those Caucasian names with the fewest positive responses (Kristen and Brad) (Edelman, Luca, and Svirsky, 2016, 12).

This type of screening is a practice that could not occur in a traditional online hotel reservation process, where the system automatically accepts reservations from any customer who can pay the fee to reserve the room. Airbnb has responded to these claims of discrimination by releasing a Nondiscrimination Policy, highlighting that the platform is "an incredibly diverse community, drawing together individuals of different cultures, values, and norms" (Airbnb, 2017, Nondiscriminatory Policy). In late 2016, they made all hosts and guests accept a terms of use agreement which enforces their two foundational principles of inclusion and respect and explicitly states that no user will discriminate on the basis of race, religion, national origin, ethnicity, disability, sex, gender identity, sexual orientation, or age (Airbnb, 2016, Policy Tool 
Chest, 9). The company has attempted to combat discriminatory claims through a series of recent advertisements, including a prominent television commercial that aired during the 2017 Super Bowl featuring the faces of people of different genders, ages, and of different ethnic and religious backgrounds pasted together under the Twitter hashtag, \#weaccept (see Figure 3).

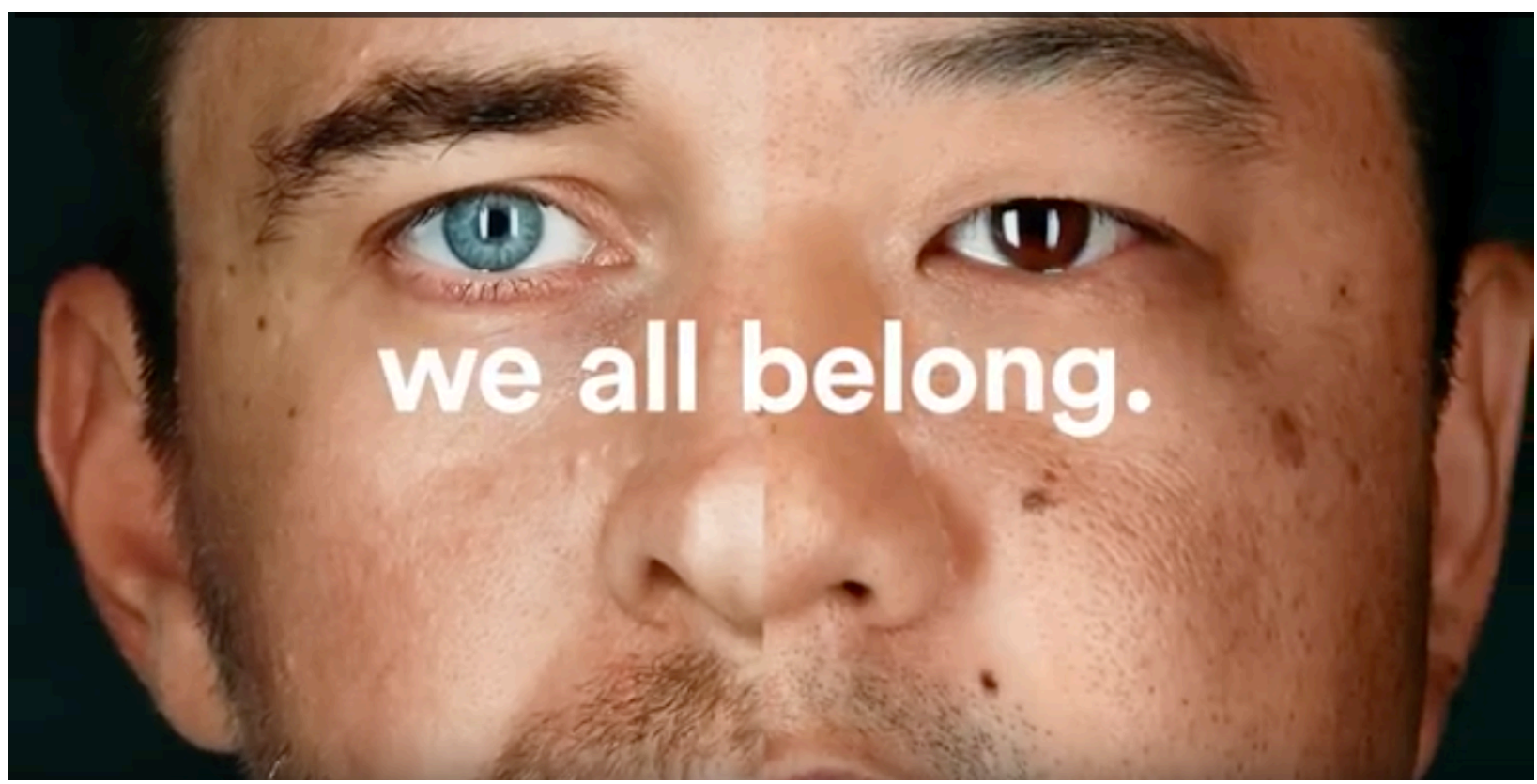

Figure 3: Screenshot from the Airbnb Super Bowl 2017 televised commercial combatting the image of discrimination on the platform (Benner, 2017).

Although Airbnb has made an effort to address discrimination on their platform, hosts continue to have the ability to screen guests, although they now must provide a reason why they are declining a potential booking which is recorded by the company. It is, therefore, unlikely that the discrimination underscored by Edelman, Luca, and Svirsky (2016) will have changed much in the wake of Airbnb's new policies. Municipal regulators need to be aware of the possible discrimination that these types of platforms introduce and find ways to understand the impact of the technology in their cities.

\section{Access to Data and Issues of Privatized Enforcement}


To understand the many ways in which digital platforms impact cities and to develop stronger policies to deal with these changes, municipalities need to find new ways to approach technology and acquire the data they need. In the case of Airbnb, cities have resorted to two main strategies: enter into data sharing agreements with the company or else use private enforcement consultants to gather data that is publically available online.

Airbnb has been attempting to standardize the data that they provide to municipalities through their Community Compact initiative, in which they publish specific generalized data about cities in which the company has a large presence (Airbnb, Policy Tool Chest, 2016, 11). This includes data on the annual economic activity generated by the Airbnb community, average income earned by hosts, the general geographic distribution of listings, percentage of hosts sharing entire units, the average number of days that listings are rented, and the safety record of their listings (Airbnb, Policy Tool Chest, 2016, 11). The trouble is that this data is not very rich and only provides a static picture of averages across the entire municipality. For example, a map of the geographic distribution of listings on their community compact website, shows where general concentrations of listings are, but no real ability to calculate density in different neighbourhoods or any sense of how listing

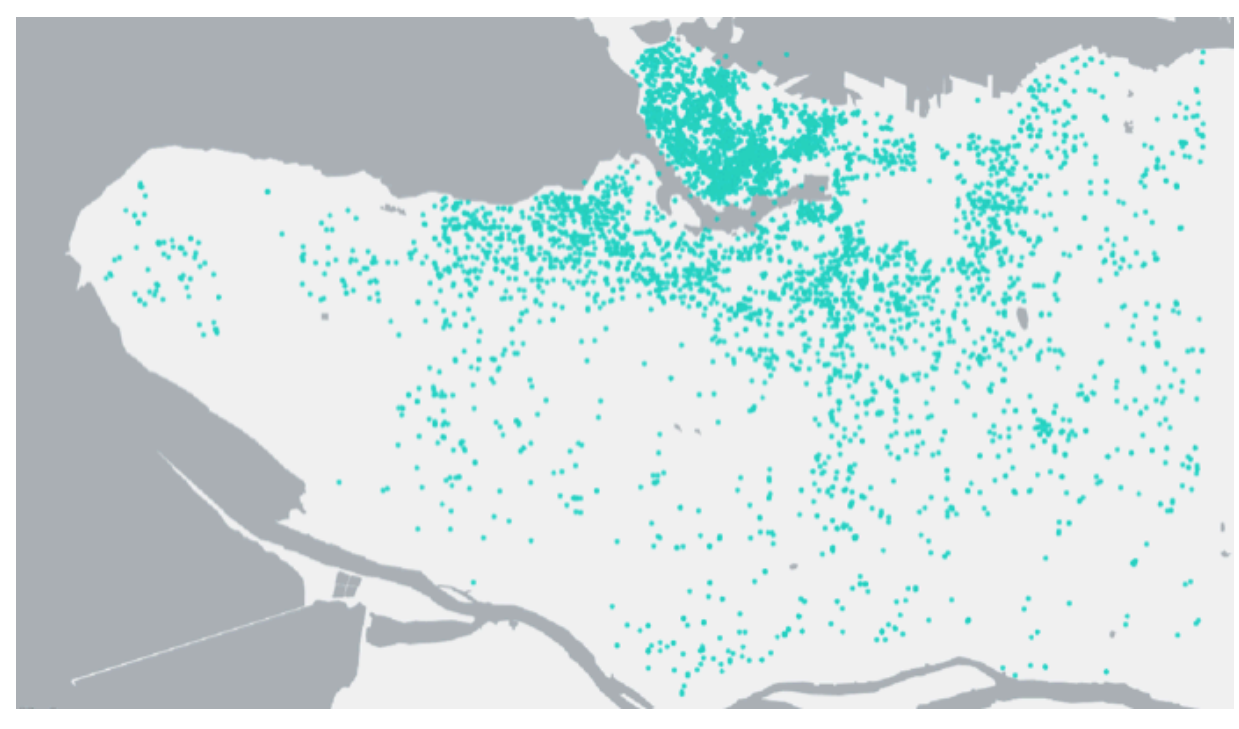

Figure 4: Screenshot of static picture of the distribution of Airbnb listings in the City of Vancouver (Airbnb, 2017).

are changing over time (see Figure 4; Airbnb, Overview of Vancouver, 2017). While individual 
municipalities have been more or less successful at acquiring richer data from Airbnb, these negotiations are handled on a case-by-case basis and it is difficult to see what data each city has obtained from the company. Some municipalities also suggest that there have been compliance issues with Airbnb sharing data regularly (list specific incidences, i.e. San Francisco, New York City etc.).

The second option currently utilized by a number of municipalities in order to acquire data about short-term rentals is hiring private consultant companies to perform web scraping scans of the Airbnb website and prepare reports for City staff (provide examples, Vancouver etc.). One of the most popular consultant groups is Host Compliance, a company that offers different packages including trend monitoring, address identification, compliance monitoring, and tax collection support for an annual fee (Host Compliance, 2017). Yet the privatization of data collection and enforcement introduces a new series of challenges for municipal staff in ensuring accurate data, legal data collection techniques, resources to fund policies that require such levels of privatized enforcement, and broader questions about the extent to which public/private partnerships might play a role in bylaw enforcement. 


\section{Methodology}

The analysis presented in this research paper is contextualized by the preceding literature review of scholarship pertaining to the development of digital platforms and the challenges that the short-term rental platforms present to municipal regulators. This information comes from academic sources, such as published manuscripts and periodicals, as well as government reports, newspaper articles, and company documents.

This research study follows a mixed method approach, blending quantitative data analysis, complemented with jurisdictional content analyses, and qualitative interviews with key informants. In preparation for the data collection and interviews, this study was granted approval by the Ryerson University Research Ethics Board. Quantitative data was gathered through InsideAirbnb, an "independent, non-commercial set of tools and data" (InsideAirbnb, 2017). The website performs scrapes of the public Airbnb website every six months and provides this data at no cost to the public in the form of comma-separated value files. The files contain geographic locational data and quite an extensive number of variables including unit descriptions, unit type, cost, calendar availability, amenities, number of host listings, and reviews. The dates at which each scrape was performed were June $7^{\text {th }}$ and September $3^{\text {rd }}, 2015$, and July $5^{\text {th }}$ and December $4^{\text {th }}, 2016$. The boundaries for each scrape were the municipal boundaries of the City of Toronto.

A jurisdictional scan was completed in order contextualize the challenges surrounding short-term rentals in three key governments: San Francisco, Chicago, and the province of Quebec. At the time of writing this scan in late 2016, these regions had the most extensive regulatory framework surrounding the Airbnb platform and might serve as important precedents to the Toronto regulatory context. 
Finally, five key informants selected for this study include municipal or regional planners, regulators, and short-term rental policy development professionals. These interviews focused on the approaches that City staff take toward regulating digital platforms like Airbnb, the strategies they employ in tackling new technologies, difficulties accessing sufficient data, positive and negative impacts of the technologies, and questions surrounding the monitoring and enforcement of policies. Interviews were semi-structured and lasted approximately 45 minutes. 


\section{Different Regulatory Approaches to Short-Term Rentals}

In the past five years, online short-term rental platforms, such as Airbnb, have expanded rapidly throughout North America and facilitated easier access to and promotion of residential units to transient populations. This disruptive technology has only recently drawn the attention of larger North American municipalities, who have begun to put into place regulatory frameworks to deal with the licensing, zoning, insurance, and taxation concerns surrounding the practice (Ted Rogers School of Management, 2016). To date, however, the regulations surrounding short-term rentals such as those offered through Airbnb in Toronto have remained unclear.

In order to assess the current state of short-term rental regulations in the context of the City of Toronto, this chapter first examines the history of short-term rentals throughout the city by looking at policies developed throughout the twentieth century. The subsequent section presents a brief jurisdictional scan of three different regulatory approaches adopted by other municipalities and provincial governments. The chapter then concludes by suggesting possible avenues through which the City might regulate the practice in future within current legislative parametres laid out by the Province of Ontario.

\section{The History of Residential Short-Term Rentals in Toronto}

Prior to the establishment of digital peer-to-peer networks, discussions about the regulation of short-term rentals were usually encapsulated in larger conversations about rooming houses and bed and breakfast establishments. Philippa Campsie (1994) notes that rooming houses were common and unregulated in Toronto in the 1940s as respectable temporary lodgings for students, single workers, immigrants, and newlyweds. In the wake of the development of 
affordable suburban houses, however, these rooming houses became precarious housing in the 1960s for those with no other options, such as students, the working poor, or the unemployed (Campsie, 1994). The subject of social stigma, many rooming houses fell into such a state of disrepair that they became a public health and safety concern which the municipality felt the need to regulate. After 20 people died in rooming house fires during the winter of 1973-1974, Toronto City Council passed two by-laws requiring owners of rooming houses with five tenants or more to obtain a license, submit to yearly inspections, and meet fire standards (Campsie, 1994). Yet, the imposition of these regulations meant that rooming-house owners sought out high profit margins, charging higher nightly fees to guests and in some cases becoming hotels or motels outright.

As the number of affordable rooming houses declined in Toronto, the provincial government struggled to find new sources of affordable housing. The Bairstow Report commissioned by the Ontario government in 1986 concluded that one way to create new affordable housing options would be to encourage homeowners to rent out portions of their homes. It identified that 850,000 dwellings across the province had extra space available which, if rented out, might provide a privately-funded source of affordable housing that would boost the incomes of homeowners simultaneously (Campsie, 1994). While some skeptics felt that people would not choose to have others live with them unless they were already in difficult financial situations, this observation anticipated the change that would occur a few decades later with the advent of digital platforms like Airbnb.

It was also in the late 1980s that Bed and Breakfasts were becoming more popular throughout Ontario. Having originated in the Maritimes where individuals would open their houses up for short-term accommodation throughout the summer season, Bed and Breakfast 
establishments in Ontario fell under Tourist Homes legislation created in the early twentieth century (Honor, 2015). According to this legislation, families were permitted to rent out up to four rooms within their homes without having to formally register as a hotel or motel. It was only once the Hotel and Motel Association began lobbying the provincial government to put these smaller establishments under the same regulatory scrutiny as larger establishments that specific legislation was developed (Honor, 2015). Bed and Breakfasts in Ontario now need to conform to building and fire codes, smoking and food safety regulations, and municipal zoning bylaws. In Toronto, however, there is no licensing system for bed and breakfasts or other tourist establishments.

The Toronto Zoning By-Law does continue to permit Tourist Home uses in residential areas, stating that these must be the "principle residence of the tourist home operator; cater to the needs of the travelling public by the furnishing of sleeping accommodations; and may include the provision of meals" (Toronto Zoning By-Law 596-2003, 860). One of the core problems with this municipal legislation, however, is that there is no legal definition of the concept of "principle residence" either in the Zoning By-Law itself or in any provincial legislation (City of Toronto, 2016, 6).

While the ambiguity of this legislation is certainly an area of concern for municipal regulators who seek to provide clearer distinctions between hotel and tourist home uses, the bigger challenge is recognizing that new digital platforms allow for more flexible transitions between traditional uses. The same property might function as a rooming house for one guest, providing longer-term residency in a shared house, while acting as a tourist home for another guest only spending one night in a separate room. The owner of that same property might usually occupy the space, but choose to sleep on a friend's couch to make a profit by renting out 
their own room in the house several days a week. Legal definitions quickly become more complicated than those with which zoning by-laws can easily cope. Furthermore, it is very difficult to detect any short-term accommodation uses, as short-term rental space is not distinguished from surrounding residential properties in any physical manner and listing can be posted online or removed very quickly.

\section{Three Different Approaches to Short-Term Rental Regulation}

While the City of Toronto is currently investigating the different methods of regulating short-term rentals, it is useful to examine the manner in which this has been done in other North American municipalities. This jurisdictional scan will focus on the methods employed in San Francisco, Chicago, and throughout the province of Quebec. A discussion of the problems associated with these methods follows the survey of the three regions.

City of San Francisco

As the city where Airbnb headquarters are located, San Francisco became one of the earliest municipalities in the world to legalize short-term rentals. In October of 2014, City Council passed an ordinance that primarily regulates the operators of short-term rentals through the creation of the Office of Short-Term Rentals and the Short-Term Residential Rental Registry (City of San Francisco, 2014, Ordinance No. 218-14). The ordinance stipulates that the operators of short-term rentals must be permanent residents of the city (meaning that they must have occupied a residential unit within the City for at least 60 days), have only one short-term rental unit, and must demonstrate that the unit has liability insurance greater than $\$ 500,000$. If the operator meets these requirements, they can submit a $\$ 50$ application to be put on the Short- 
Term Residential Rental Registry and are required to collect a 14\% Transient Occupancy Tax along with each rent payment to be submitted annually to the City. It is estimated that in 2015, the amount of tax collected from Airbnb transactions alone amounted to approximately $\$ 15$ million, or $4 \%$ of the total Transient Occupancy Tax revenues collected by the municipality (Budget and Legislative Analyst's Office, 2016, 24). San Francisco has also stipulated that operators may only rent out their spaces 90 days a year unless they are physically present in the unit (literally sharing the home they occupy with a guest).

\section{City of Chicago}

Whereas San Francisco opted to regulate proprietors, the City of Chicago chose to regulate short-term rental intermediaries as well as short-term rental units themselves (City of Chicago, Ordinance 2016-341). An ordinance was passed in June 2016 requiring short-term intermediaries (i.e. digital platforms like Airbnb) to acquire an annual license to operate that is $\$ 10,000$ if the intermediary as 1,000 or more short-term residential rentals listed on its platform or $\$ 5,000$ if it has 999 or fewer units listed. Further, all intermediaries must guarantee that they are insured, provide contact information to the City, comply with tax collection, and monitor listings on their platform to ensure that they also are in compliance with local bylaws. Shortterm rental proprietors must also register each of their units with the city and list their registration number on their advertisements of the rental, openly state if the unit is wheelchair accessible, provide a description of the number of sleeping rooms and bathrooms available, and whether the unit has parking, or access to recreational facilities. The rents collected from any unit are subject to a $4.5 \%$ Hotel Accommodations Tax as well as a $4 \%$ surcharge on for Vacation Rentals and Shared Housing, for a total of $8.5 \%$. The State of Illinois also collects a Hotel 
Operators' Occupation Tax which is roughly 7\%, however, they have not yet begun to enforce this tax on Airbnb operators (State of Illinois, 35 ILCS 145/1).

Beyond the regulation of intermediaries and units, the City of Chicago has also stipulated a number of operating requirements which are quite distinct from the parameters laid out in San Francisco. This includes requiring proprietors to "provide guests with soap, clean individual bath cloths and towels, and clean linen" as well as "to clean and sanitize the shared housing unit and all dishes, utensils, pots, pans and other cooking utensils between guests, and dispose of all food, beverages and alcohol left by the previous guest" (City of Chicago, Ordinance 2016-341, 4-9-050). What is less clear is how the City intends to enforce these particular regulations beyond receiving complaints.

Province of Quebec

Unlike San Francisco and Chicago which regulate short-term rentals at a municipal level, the province of Quebec was the first provincial government to regulate these practices within Canada (Quebec, Chapter E-14.2, r.1). The regulation system requires proprietors to register their units with the province in order to obtain a $\$ 250$ classification certificate that permits them to rent it on a short-term basis. This certificate registers the type of unit provided, as well as the operator's name and contact information, the address of the unit itself, and a description of the services offered. It also requires proprietors to demonstrate ownership of their unit and proof of civil liability insurance no less than $\$ 2,000,000$. Finally, all short-term rentals are subject to the provincial Lodging Tax which is currently set at 3.5\% provided that the rental lasts longer than 6 hours and less than 31 consecutive days (Revenue Quebec, 2016). 
Problems with Regulation

While these efforts to regulate short-term rentals have all adopted different approaches and show the range of possibility in terms of the creation of bylaws, several studies have demonstrated common problems that exist for these municipalities in the enforcement of the regulations. By far, the city with the most comprehensive data in regards to enforcement is San Francisco, where laws were enacted earlier than in other municipalities and due to the fact that the Budget and Legislative Analyst's Office is required to publish a publically accessible Policy Analysis Report on short-term rentals annually.

One of the initial findings of these reports is that despite the fact that the City has created a manner of legally renting units on a short-term basis, most proprietors remain out of compliance and have failed to register with the Office of Short-Term Rentals. Only $20 \%$ of unique Airbnb hosts have registered and complied with local laws. Beyond this, it is estimated that of that $20 \%$, at least $26 \%$ of proprietors are breaking the 90 -night cap on renting entire private units (Budget and Legislative Analyst's Office, 2016, 2). The province of Quebec has also experienced a similar lack of compliance with provincial laws, reporting that only 500 rental permits have been issued throughout the entire province, and only 41 in the City of Montreal where over 10,000 units are listed online (Marowits, 2016).

The second problem with current methods of regulating short-term rentals is that enforcement generally only occurs in response to complaints from neighbours. This is in part due to the fact that data on listings has typically not been openly shared with municipalities by companies that create digital platforms. While Airbnb has partnered with some cities to ensure that taxes are collected automatically whenever a transaction is performed, it has been less willing to monitor listings to ensure their compliance with local laws. Without the ability to 
perform independent web scrapes of online platforms, municipalities must rely on third-party data collection to identify transgressions and ensure compliance.

\section{Avenues for Future Regulation of Short-Term Rentals in Toronto}

The discussion of different jurisdictional practices in regards to the regulation of shortterm rentals suggests that the main avenues of regulation at a municipal or provincial level involve licensing, zoning, and taxation. The following section will bring each of these issues forward in the context of the City of Toronto.

\section{Licensing}

The City of Toronto currently does not require any hotel or short-term rentals proprietors to acquire any special registration or licensing, however, they do have the power to create a new licensing system which could help to ensure that units conform to building, health, and safety standards. Such a registry could potentially provide more detailed data on the location shortterm rentals throughout the city and give the municipality much more detailed information on the practice. It is worth noting that other municipalities have struggled with non-compliance in response to the development of a registry system. This would mean that the enforcement of this system would likely only be effective if the City was able to negotiate with Airbnb to provide data on listings throughout the municipality. This agreement to transfer data might be possible through the licensing of intermediaries as was modelled in the City of Chicago.

In terms of increasing City revenues, licensing systems in the jurisdictions considered in this paper ranged from $\$ 50$ to $\$ 250$ annually. Applying this fee range to the short-term rental apartments in Toronto offered through Airbnb would mean that revenue would range from 
$\$ 510,350$ to $\$ 2,551,750$ if all proprietors complied with the law, only a modest increase in the total city budget. As San Francisco had the highest compliance rate at $20 \%$ of the total available units, however, a more realistic projection of revenue following these numbers would be $\$ 103,050$ to $\$ 516,000$. This amount of revenue might make it difficult to render the registration program fiscally neutral.

\section{Zoning}

It would also be possible for the City of Toronto to regulate the practice of short-term rentals through the Zoning Bylaw, as was done in the case of rooming houses in 2009 (Chief Planner and Executive Director, City Planning, 2009, 4). The Zoning Bylaw is a regulatory tool that is permitted under the Planning Act and would allow the City to control the intensity of use regarding short-term rentals. In 2009, the Supreme Court of Canada dismissed a case challenging the City of Oshawa's right to distinguish between single detached dwellings and lodging houses, suggesting that municipalities do have the ability to distinguish "short-term temporary sleeping quarters and shared facilities on a rental basis" (Chief Planner and Executive Director, City Planning, 2009, 4). By classifying short-term rentals as a distinct use, the City might be better able to control where these units are situated throughout Toronto. Once again, however, this is difficult to enforce without access to proprietary data.

A benefit of regulating short-term rentals through the Zoning Bylaw is that it has the potential to combat the impact short-term rentals have on the long-term rental market, by controlling where this use is permitted throughout the city. In areas where the vacancy rate is particularly vulnerable, it might be beneficial for the city to prioritize long-term rental uses. 
Taxation

Within Ontario, provincial jurisdiction over municipalities means that any introduction of regulations for short-term rentals would require provincial approbation, as no municipality currently has the authority to introduce lodging taxes. After the City of Toronto was amalgamated, the municipality approached the province in an effort to obtain the authority to collect a hotel tax, however, the province denied this request (Rossini, 2016, 1). The City of Toronto Act issued by the Province of Ontario in 2006 explicitly prohibits the municipality from levying such a tax, stating that the City is not allowed to introduce:

A tax imposed on a person in respect of lodging in or the use of the rooms or other facilities of a hotel, motel, hostel, apartment house, lodging house, boarding house, club or other similar type of accommodation. (City of Toronto Act, s. 267.2.6)

Hotels and other accommodation providers are permitted, however, to contribute voluntarily to a Destination Marketing Program in order to support regional tourism marketing development (Ministry of Tourism, Culture, and Sport, 2016). Hotels in Toronto, Brampton, and Mississauga currently voluntarily collect $3 \%$ on room revenues for this purpose, which funds are paid through the Greater Toronto Hotels Association to Tourism Toronto (KPMG, 2016, 102). This voluntary tax allowed the City to stop using other revenues to support Tourism Toronto. In 2014, the voluntary program generated approximately $\$ 20$ million, or 59\% of Tourism Toronto’s total budget (Rossini, 2016, 2). Tourism Toronto uses its budget to finance major City tourism events, such as Nuit Blanche (Rossini, 2016, 2). To date, there has been no facilitated effort to encourage short-term rental proprietors to contribute toward the Destination Marketing Program. It is worth noting that it is unlikely that the Province of Ontario would change the City of Toronto Act to permit a lodging tax without also introducing the same change to the Municipal Act. This is due to the fact that the introduction of a hotel tax within the City of Toronto, but not 
in surrounding municipalities might create an imbalanced market with tourists seeking lodging in the surrounding municipalities where taxes are lower than in Toronto.

KPMG further noted in a recent study that any imposition of a hotel tax would have to be paid in addition to the $13 \%$ HST rate and that currently hotels in North America tend to pay between 14-17\% total (KPMG, 2016, 101). Even extending these figures somewhat would mean the City could only charge somewhere in the vicinity of $1 \%-8 \%$ and that a portion of this tax revenue would need to go toward Tourism Toronto's annual operating budget (KPMG, 2016, 102).

By applying the same tax to hotels and short-term rentals, the City would be reducing the impact that companies like Airbnb have on the hotel industry by ensuring that all competitors face the same tax burdens. However, the imposition of this tax on short-term rentals would likely only work in conjunction with a registration system as described above and the tax would be best collected and transferred through an intermediary. The City should also note that shortterm rentals that are listed through an intermediary are also often subject to user fees by the platform providers themselves. In the case of Airbnb, proprietors are charged 3\% on each booking and travelers are charged between $6 \%-12 \%$ (these amounts are also subject to change at any time). Even if the City were unable to convince the province to permit municipally imposed lodging taxes, it might be more beneficial to begin this process informally by simply extending the Destination Marketing Program to short-term rental proprietors on a voluntary basis. If the City were eventually able to collect a lodging tax, a component of the amount paid by short-term rental proprietors could be funneled into affordable housing in order to combat the negative impact mentioned above. 


\section{Data Collection for the Digital City}

One of the central struggles that municipalities have been facing surrounding the expansion of short-term rental platforms has been regular and reliable access to data pertaining to the practice. As there is no need to physically demarcate short-term rental units so that they might be visible from the street, nor any need to advertise them beyond major digital platforms, it can be extremely difficult for City staff to effectively study the phenomenon. While some municipalities have tackled this problem by entering into data sharing agreements with major platforms in the field, these agreements are built upon the good-will of the company to submit data that could potentially undermine the viability and profitability of their platforms.

For this reason, it is important that municipal staff begin to explore the use of other sources of data which do not rely on information provided only by a major platform. Data sharing agreements should focus on the requirement that major companies offer Application Programming Interfaces (APIs) and that the City has the means to acquire reliable information from them. In the absence of APIs, web scraping is an underutilized tool which has proven to be a useful tool in the regulation and enforcement of the short-term rental market.

This chapter will discuss new tools that municipalities might be able to employ in order to tackle data shortages and will use data collected through these methods in order to analyze the short-term rental market in the context of the City of Toronto. It first outlines methods of data collection, considers issues of legality surrounding the use of these new methods, analyzes web scraped data provided by InsideAirbnb.com, and finally addresses the limitations of these tools.

\section{How Web Scraping Works}

An increasingly important tool for municipalities to consider using as digital platforms continue to expand is web scraping - a practice that refers to the automated gathering of data 
from the internet (Mitchell, 2015, 9). Using simple programs, it is possible to query a web server, request specific data, and then have that data automatically inputted into a separate database which can be used in different contexts. This is not a new technology and is similar to the basic code behind all web searching engines like Google and Yahoo!. In the case of Google, this process of gathering data is done by Googlebot, a 'spider' that crawls through websites looking for links to new pages and then adds relevant data, such as page titles and abbreviated content, to their database (Google, Googlebot, 2017). Many websites have also begun to use this technology in order to amalgamate data from multiple different websites into one centralized source. For example, the website Padmapper.com gathers data from a number of rental websites and displays them on one map, and Indeed.com publishes data from different job posting websites on one page.

In some instances, companies make this process of retrieving data easier and more licit by creating their own Application Programming Interfaces (APIs), a tool which facilitates data queries through a standardized process. Developing APIs allows separate programs or platforms to interact with one another, such as Twitter posts which are simultaneously posted on Facebook, or Yelp's ability to display the location of nearby restaurants on Google Maps. APIs are also useful in that they formally define the types of inquires that can be made of their databases, allowing developers to know who is using their data, how frequently, and what information they are requesting.

While companies normally develop APIs in order to increase the profitability and scope of their business, this could become a tool that might strengthen future data sharing agreements with municipalities and could be more conducive toward building an effective regulatory enforcement strategy. The benefit of this type of model is that it would give municipal staff 
more control over the regular access to data, as they would be able to cater their requests to suit specific needs as they arise. The data that is pulled would be live and therefore more reliable, as the company itself would not just be releasing potentially cleaned up snapshots of what is occurring. Using an API is also a more accurate way of obtaining data than web scraping, as it provides data directly from a provider's database, rather than collecting it from public websites. Finally, municipal regulators would be better able to track changes over time, for example keeping their own records of short-term rental locations and earnings over time.

While APIs work in the context of a market monopoly, where one company dominates an industry or field, they work less well in markets with a fair amount of competition. In this instance, it becomes necessary for municipalities to be able to use web scraping techniques in combination with any available APIs in order to construct a more complete picture of digital activity. A good example of where this type of technique might be beneficial today is the longterm rental market, where landlords list units across many different sites such as ViewIt, Kijiji, PadMapper, Craigslist, through realty sites, or even on Airbnb. Being able to draw together data from different digital platforms would enable municipal staff to understand the rental market much more deeply, rather than relying on the data produced by the Canadian Mortgage and Housing Company (CMHC) which is based principally on purpose-built rental buildings (CMHC, Methodology for Rental Market Survey, 2017). Gathering this data would also likely provide municipal regulators with a better picture of all secondary and unpermitted suites throughout the city.

\section{Legal Issues Surrounding Web Scraping}

Although web scraping has become a common part of web culture, the legality of the practice is still under scrutiny with Canada. Technically, web scraping could be as simple as a 
person sitting down and recording web data in a spreadsheet, however, once again the issue of scale that is introduced by the automation of technology complicates the picture.

There has only been one relevant case involving web scraping brought before the Supreme Court of British Columbia in 2011 to date that provides some gauge as to the legal issues pertaining to the practice. In this instance, Century 21 Canada brought Rogers Communications to court over a breach of contract related to their Terms of Service Agreement which prohibited scraping by a platform that Rogers had acquired in 2008 called Zoocasa (Century 21 Canada v. Rogers Communication). Zoocasa scanned the web for listings of houses for sale from multiple providers and reposted the contents of those listings within their own interface. The questions arose regarding whether or not a Terms of Use Agreement for a public website constitutes a legally binding contract despite a user not formally agreeing to abide by those terms, and about the potential for copyright infringement. The court determined that both contract law and copyright law applied in this case and held Zoocasa responsible for these violations. In particular, the judge referred to American case law examples, stressing the importance of the concept of "transformative use" in relation to web scraping practices, stating:

A work is 'transformative' when the new work does not 'merely supersede the objects of the original creation' but 'adds something new, with a further purpose or different character, altering the first with new expression, meaning, or message. (Century 21 Canada v. Rogers Communication, 228)

Thus, search engines are not in breach of copyright law because they constitute a transformative use and they provide the means for individuals or companies to opt out from their data collection. Zoocasa, on the other hand, was a direct competitor of Century 21 Canada and was wholly copying content to their own digital platform and did not represent a transformative use. In the case of municipalities collecting data for analysis or enforcement purposes, it is unlikely that these issues surrounding copyright law would hold much weight, especially as the 
data would not be shared with the public at large. A more concerning issue in relation to web scraping is the potential breach of contract laws that might occur through the violations of Terms of Use Agreements. Using Airbnb as a case study, a similar clause exists in their own Terms of Service Agreement, which states that users will not:

use manual or automated software, devices, scripts, robots, backdoors or other means or processes to access, 'scrape', 'crawl', or 'spider' any web pages or other services contained in the Site, Application, Services, or Collective Content. (Airbnb, 2017)

Despite this clause, municipalities throughout Canada have begun to hire consultancy agencies to provide needed data which employ web scraping practices.

In the short-term rental market, Host Compliance has emerged as a leader in providing detailed data about local markets. Recently hired by the City of Vancouver, the company is vague about the practices it employed in order to conduct its study of the local short-term rental market, never mentioning the term "web scraping". Instead, it notes that the company "has developed a set or proprietary data and analytics tools that can provide deep insights into the scale and scope of the short-term rental activity in any community" (Host Compliance, 2016, 2). It further specifies that data is collected weekly from 16 top short-term rental listing sites and provides details about listing sites, the room type, number of nights the listing is available for rent, and indicators of its activity (Host Compliance, 2016, 2-3). While the municipality itself might not be held liable for a potential breach of contract because they employed a separate company to conduct this analysis, it is clear that there is a need for this type of data to create effective and enforceable policies. Rather than avoiding the issue of web scraping, however, it would be better to have more concrete legal definition of the term "web scraping" and a better sense of whether or not Terms of Service can or should prevent municipalities from gathering data. 
Once again, the broader use of APIs would help to regulate who has access to data, what information they can extract, and how often. Airbnb co-founder Brian Chesky has suggested that his company is moving in the direction of developing an API and this language is mentioned throughout their own Terms of Service, suggesting that it will become available in the future (Heine, 2016; Airbnb, 2017). Despite this, legal questions still remain regarding whether municipalities can use web scraping as a tool for data collection.

\section{Web Scraping and Short-Term Rental Trends in Toronto}

Despite questions surrounding the legality of the practice, there is no question that web scraping has played a large role in informing municipal regulators about the extent and implications of short-term rentals. In particular, the work of Murray Cox and Tom Slee through the website InsideAirbnb has been used both by journalists and municipal staff to obtain basic numbers and statistics related to short-term rental listings (Dhillon, 2016; Jamasi and Hennessy, 2016, 22; Fidalgo, 2016, 5). Cox and Slee state that InsideAirbnb is an "independent, noncommercial set of tools and data" with the particular agenda of understanding its impact on the long-term residential housing market (InsideAirbnb, About, 2017). Twice a year, the website publishes web scraped data from Airbnb within major municipal markets, including Toronto. Examining this data demonstrates the amount of information that can be obtained through web scraping practices. 
Within Toronto, Airbnb listings have been increasing over throughout 2015 and 2016. According to scraped data released by InsideAirbnb, there are an estimated 12,029 listings currently available throughout the city, a figure which increased nearly $6 \%$ per month over the 19-month period extending from June, 2015, to December, 2016. The distribution throughout the city is uneven, with outer city neighbourhoods only having 0 to 5 listings per square kilometre and the inner core ranging from 10 to 50 listings per square kilometre (see Figure 5). There are pockets within the downtown core and along Yonge Street with particularly high

\section{Density of Airbnb Listings per Square Kilometre}

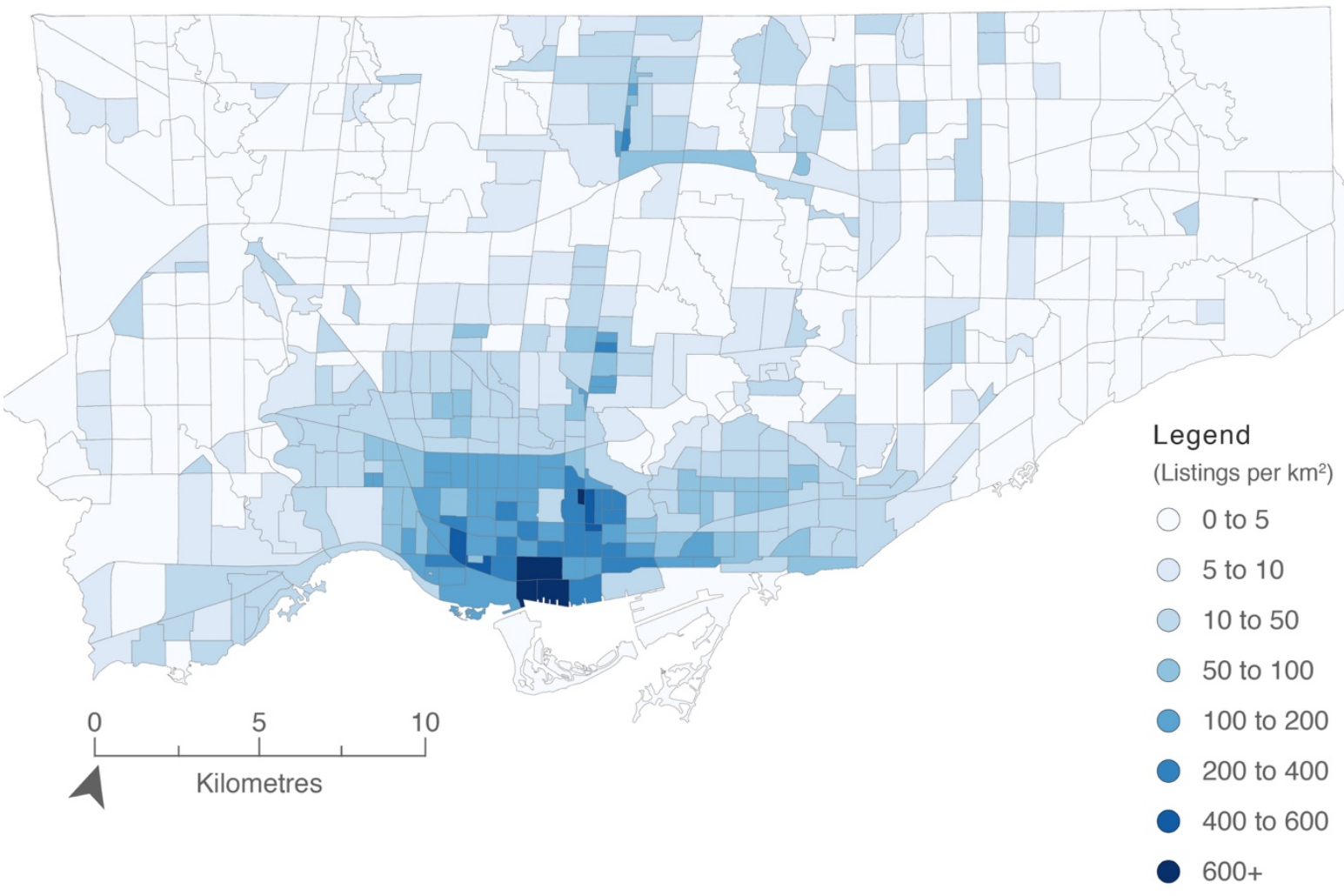

Figure 5: Map showing the density of Airbnb listings throughout the City of Toronto

density, particularly between Queen Street West and Lakeshore Boulevard in the north and south respectively, and Bathurst Street and University Avenue to the west and east where density levels increase to over 600 listings per square kilometre. The rates of growth within Toronto 
Census Tract areas presents a different story, however, as outer city areas have generally seen more significant increases since June 2015 (see Rate of Change map).

\section{Rate of Change in Airbnb Listings, June 2015 - Dec 2016}

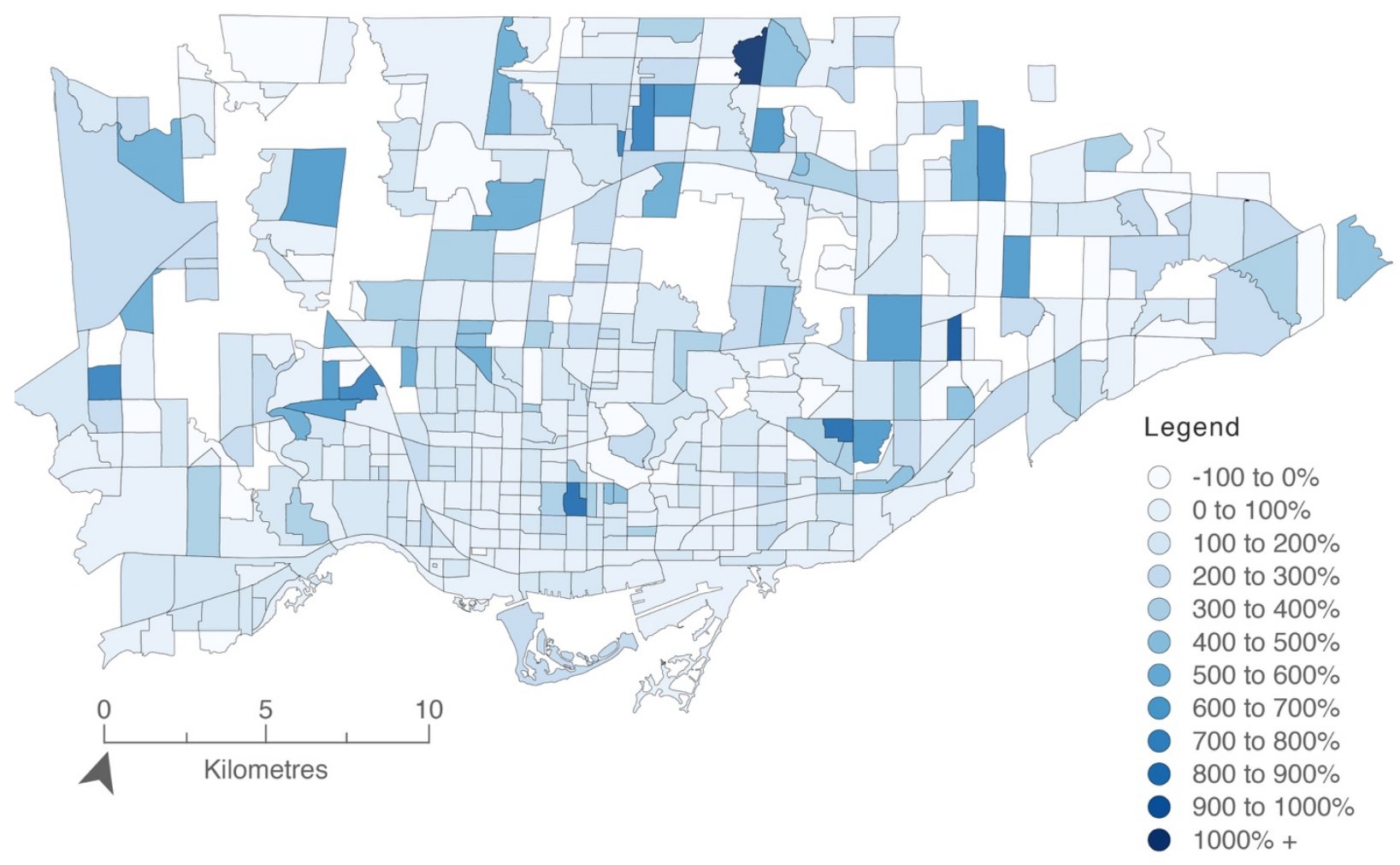

Figure 6: Map showing census tracts with the highest rates of change throughout the City of Toronto.

More important for understanding the impact that Airbnb might be having on the long-

term rental housing market more generally is a closer examination into the types of spaces listed on the platform. Airbnb distinguishes between three types of listings: entire homes, private rooms, and shared rooms (see Figure 7). Within Toronto, 63\% of all listings are classified as entire homes, which are private units that generally include amenities like a kitchen and bathroom, as well as a sleeping area (these can be full houses, apartments, or condominium units). Private rooms make up about a third (35\%) of the total listings, and include listings featuring a private sleeping space with shared common areas, such as kitchens and bathrooms. 
In some instances, Airbnb hosts live in these units along with short-term rental guests, but in other circumstances a host might list each room individually on the platform. This means that the unit is shared either between long-term residents and short-term guests, or else entirely by separate groups of short-term guests. Finally, a small fraction (3\%) of listings on the platform are shared rooms, which are defined as entirely shared spaces and might have multiple shortterm renters sleeping in the same room like in a hostel. The distribution of entire home and private room listings is balanced throughout the city, however, shared room accommodation tends to align more closely with areas of higher listing density, such as the downtown core and along Yonge Street. It is also significant that the private and shared room categories have been growing at a slightly faster rate (6\% per month) than entire homes (5\% per month).

\section{Total Airbnb Listings, December 2016}

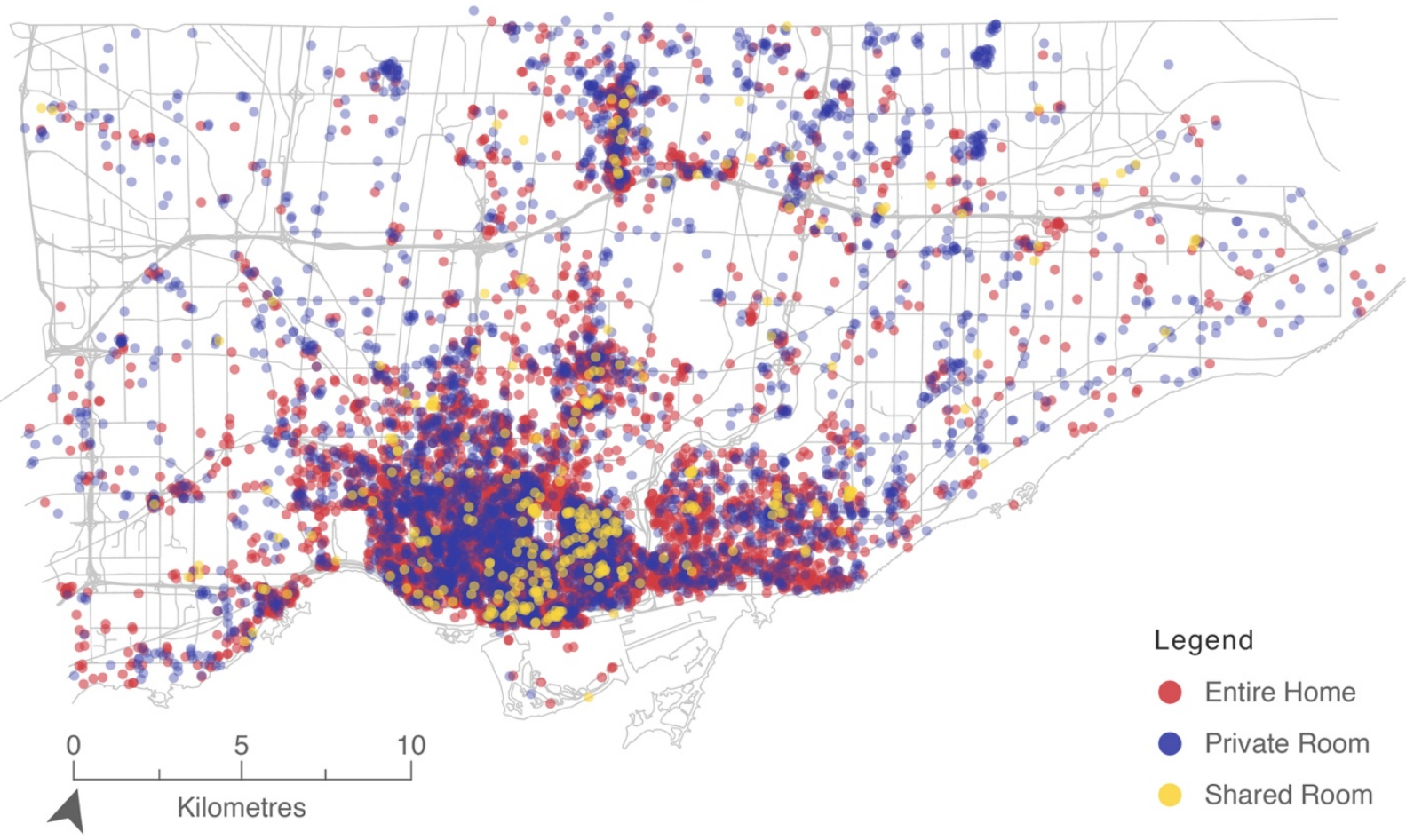

Figure 7: Map showing the distribution of Airbnb Listings throughout the City of Toronto by Room Type. 
The length of short-term rental stays varies greatly and the Airbnb platform allows for both long and short-term stays. Although booking information is not public information and is consequently not available by means of web scraping, it is possible to obtain data on the minimum and maximum stays set by hosts. In Toronto, average minimum stays have increased from 2.5 to 4 nights between 2015 and 2016. Average maximum stays have decreased from 844 nights in 2015 to 784 nights in 2016, although this shift is less significant than the fact that $71 \%$ of hosts accepted stays of 365 days or more through the platform. This number suggests that hosts may be interested in long-term rentals, but use Airbnb either in order to reach a broader network of potential renters, or else because they are willing to mix long and short-term stays in order to minimize vacancies in their spaces. These figures are almost entirely evenly divided between different listing types with $72 \%$ of entire homes, $71 \%$ of private rooms, and $60 \%$ of shared rooms offering maximum stays of over 365 days.

The cost of rentals offered through Airbnb is also a contentious subject among those concerned about the impacts the platform is having on the long-term rental market and affordable housing throughout the city. Average prices on the platform are significantly higher than that reported for the long-term rental market by the City of Toronto from CMHC data (City of Toronto, Average Market Rents, 2016). Comparing all unit sizes, the City estimates that the average gross rental price for 2016 was $\$ 1,340$ per month. On Airbnb, the average nightly price has decreased slightly during the study period from $\$ 130$ to $\$ 123$ while the average monthly price has increased from $\$ 3,242$ in 2015 to $\$ 3,383$ in 2016 . This suggests that hosts may be discouraging longer stays by raising the price listings in the longer-term options. Looking more closely at the top ten percent of listings on the platform, the average in 2016 was as high as $\$ 8,907$ per month. Seeing as the Hotel Association of Canada estimates that the average cost per 
month for a hotel room in Toronto is only $\$ 4,230$, these fees are high even for short-term accommodation rates. Only $15 \%$ of all listings fell at or beneath the City average of $\$ 1,340$ and the vast majority of these units were private or shared room types (see Figure 8). In the entire home category, a mere $2 \%$ of units were under the long-term City average.

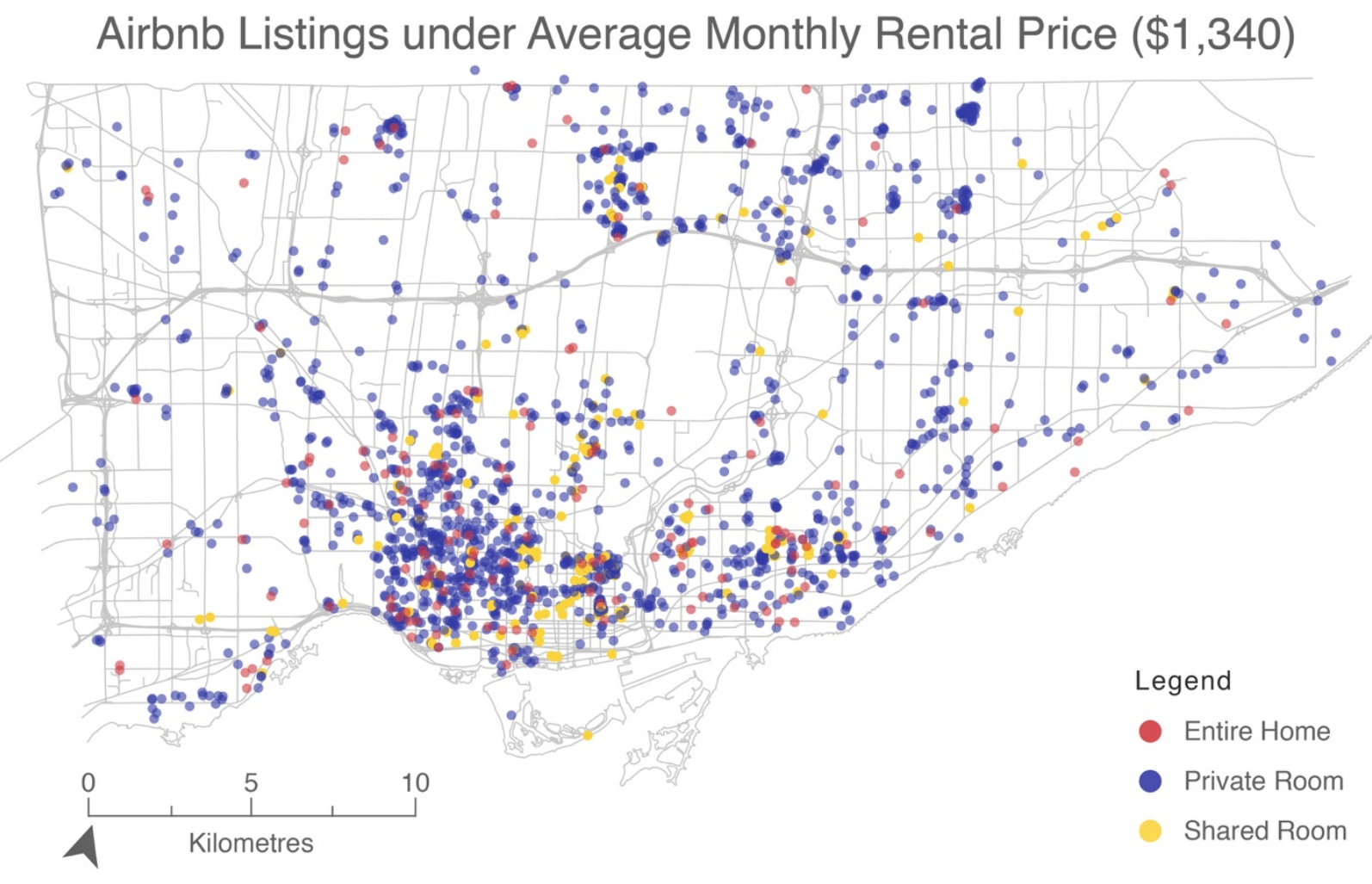

*Only $15 \%$ of all Airbnb Listings fall under the average monthly rental price

Figure 8: Map showing the distribution of Airbnb listings under the average monthly rental price by room type.

Finally, the size of units offered through the platform might be estimated by examining the number of bedrooms advertised. Airbnb appears to lend itself more to smaller units, as $78 \%$ of all listings on the platform were either bachelor or one-bedroom units, a figure which has remained almost completely consistent between 2015 and 2016. Within the entire home category, $65 \%$ are smaller units one bedroom or fewer listed, while all private and shared room 
accommodations are listed as one bedroom. It is important to note that the figures for private and shared accommodation may not be entirely reflective of how many bedrooms are in the entire unit, but rather a reflection of the number of bedrooms to which a guest might have access.

\section{Limitations of Scraped Data}

Although the ability for municipalities to perform fine-grained analyses of public data available on the internet offers great potential for studying and regulating increasingly digital cities, the data does have several limitations. First, it can only gather data that is already publically available. In the case of Airbnb or other long-term rental websites, these scrapes are fairly fruitful, as landlords typically want the general public to see their listings and there are few barriers to accessing the information. It is less easy to access data about actual rentals or bookings because that information remains private between the individual who has listed the space, the platform provider, and the renter. Any information about actual bookings made through Airbnb would need to come from the provider itself. It is possible that an API could help in this context, as Airbnb could release live anonymized access to actual booking information. This is only possible, however, because the short-term rental market is dominated by one platform, making the process of sharing data relatively straightforward.

The next most significant limitation of web scraping is that the scripts which perform data mining are generally fairly fragile and may not work if a platform provider changes the way in which it displays data on its website. For example, by simply changing the name of the room type variable on the platform, Airbnb would disrupt current scraping scripts which search for specific terms. This means that a platform can actively attempt to break scraping scripts by changing their code or content on a regular basis. Providers may also opt to transfer their content 
to a Flash platform, which cannot easily be scraped. While issues in the fragility of the code can generally be overcome, it requires technical knowledge to problem solve arising issues and regulators would not be able to rely very long on one static program designed to extract data. Once again the development of APIs would help to mitigate this problem as they tend to be more consistent and could give platform providers a say in who uses their data and to what extent.

The ability to develop and problem solve flexible scripts for the purposes of scraping websites also requires considerable technical expertise and resources which might be difficult for the City to acquire. Whereas current Information and Technology staff at the City are trained in the management and development of internal networks, they may be less equipped to deal with new requests for generating and maintaining codes capable of scraping complex digital platforms. For this reason, the City might need to invest in developing a new branch of the department specifically tasked with handling these types of requests.

Finally, there are also legal concerns which need to be more clearly addressed through Canadian courts and regulation regarding how municipalities may collect, store, and use data which could be more clearly outlined by higher levels of government. Right now the practice of web scraping falls into a legal grey area, as there have not been enough Canadian cases brought forward to test a municipality's right to collect digital information. These renders municipalities vulnerable in terms of liability. Rather than attempting to avoid issues surrounding liability by hiring a private consultant company to perform the scan, municipalities could advocate for provincial or even federal guidance on this issue in order to more clearly define whether a municipality scraping data constitutes a breach of contract if it goes again Terms of Use agreements. 


\section{Municipal Approaches to the Regulation of Digital Platforms}

In order to better understand how municipal planners and regulators are currently tackling the challenges presented by the emergence of new digital platforms, four interviews were conducted during February and March, 2017, with municipal staff and digital platform providers in the City of Toronto. Interviews were focused on issues related to broad technological change in planning practice, specific approaches to assessing the scope and extent of short-term rentals, as well as discussions of the challenges surrounding regulation and enforcement of activities on digital platforms. These interviews were recorded and transcribed before being subjected to manual content analysis in order to identify prominent themes and issues in each discussion. The prominence of themes was identified through the frequency with which themes arose and where interviewees expressed widespread agreement or disagreement.

Almost every conversation with City staff began with the acknowledgement that they did not approach the problem of short-term rentals from a technological standpoint. Instead, staff were clearly focused on specific topics related to the broader area in which they worked, for example housing policy. Despite the way they structured their approach to the problem, all interviewees were able to reflect more broadly upon the many ways in which technology and digital platforms have begun to influence their practice. In some instances, this involved direct contact with digital platform providers and in other cases mainly surrounded a discussion about the difficulties in collecting relevant data or keeping pace with rapid change. While technology may not have been the starting point of these conversations, the themes that arose all circled back to it in significant ways.

In order to better facilitate the analysis of this qualitative data, I have framed my discussion around three core thematic topics. These topics include: 


\section{Technology as an Agent of Change}

2. Importance of Strong Data Sharing Agreements

3. Creating Enforceable Policies

\section{Technology as an Agent of Change}

There was some disagreement between interviewees as to whether or not technology or digital platforms are truly altering the ways in which citizens are using their cities or should impact how staff approach planning issues in the future. One staff member noted that technology was more of a "facilitating" device than a driver of change, comparing listings that might appear on a platform like Airbnb to posting a listing on the community bulletin board of a local grocery store. The practice itself was not new, but what technology was changing was the speed at which shifts occurs and the media sensationalism surrounding these new platforms. In this sense, short-term rentals were seen as a land use which already existed prior to the introduction of new technology, but that current municipal bylaws were not written with these new technologies in mind and might consequently require updating. In particular, comparisons were made between short-term rental uses and the pre-existing concept of a "Tourist Home" in the Toronto Zoning Bylaw, which is permitted in some residential and some commercial residential zones. Thus, a planner's role was more to amend existing bylaws and policies to reflect the new practices and the scope and scale at which these activities were happening and to consider whether the use should be permitted in more areas, or whether it should be further restricted.

Other interviewees suggested that it is important to consider carefully whether or these digital platforms are really having an impact, or whether it has received a disproportionate 
amount of media attention because it involves the use of a new technology. Difficulties in obtaining satisfactory data pertaining to the technological use were mentioned in conjunction with the need to observe impacts through other means. This concern arose particularly in conversations surrounding the impact of Airbnb on affordable housing. Planners stressed that assumptions should not be made surrounding the impact of short-term rentals on the long-term rental market noting that the 12,000 units currently listed on Airbnb might add some housing supply, but many units are already shared space and are therefore not likely to become long-term housing for new families. Even of the percentage that are entire home listings, it is unclear how many are completely dedicated to short-term rentals all throughout the year and how many are temporarily empty while occupants are out-of-town or choosing to sleep at a friend or family member's residence in order to earn additional income. The question of how to measure impact on affordable housing in this context becomes quite complicated.

One point upon which there seemed to be general agreement among all interviewees was that the introduction of new technology changed the rate at which municipal government needed to conduct studies and recommend regulatory policies to council. The speed with which Uber or Airbnb have been able to operate from their introduction into the market to their formal establishment as a main competitor has been remarkably fast. Whereas municipal regulators would previously have had time to observe rising impacts, new technologies are making it harder to predict how local markets will change and what impacts these changes will have on the municipality at large. Municipal staff require more resources and technological skill in order to cope with the fast-paced change. 


\section{Importance of Strong Data Sharing Agreements}

The need for better access to data was a common theme in all interviews and tended to be an issue which we would circle back to repeatedly. All City staff expressed that relationships with digital platform providers were quite positive and that particularly Airbnb had been quite proactive in sharing the data requested by municipal government. Staff also mentioned that by far the most useful data on short-term rentals came from Airbnb itself, as the company dominates the market and can provide data on actual bookings, whereas web scraped data only provides figures on listings in the city. While Airbnb is currently providing data to the City as a gesture of good will, the City has established more formal data exchange mandates with other digital platform providers through the introduction of new regulatory policies. Most notably, Uber is now licensed as a Private Transportation Company in the City of Toronto, and a condition of obtaining that license is that data be transferred to City staff once a month. It is likely that a similar type of data-sharing agreement will also be established with Airbnb in the future.

While the relationship with Airbnb has been positive, staff also recognized that in instances where a digital platform provider does not provide data, the City "cannot turn a blind eye to the phenomenon." They also recognize that markets are not likely to be solely dominated by one platform provider indefinitely and that data provided by a company with a vested interest in operating throughout the City may not always be reliable. For these reasons, the City has begun to think about other useful sources of data which might be used in conjunction with platform-provided figures. To date, these sources of alternative information come from web scraping, data collected at public engagement events, and complaints made to the City through services like 311 . In regards to web scraped data, the City itself is not engaged in the practices of web scraping and it remains uncertain whether they have the technical or legal capacity to do 
so. In the case of short-term rentals, they have been able to use the data provided by InsideAirbnb to corroborate data released by Airbnb itself. While APIs were mentioned as a possible avenue for further research, to date Staff have not pushed for more regular access to data through APIs, but rather rely on file transfers from the company itself.

Public consultation is paramount to the development of future regulations surrounding short-term rentals and certainly was a component of developing regulations surrounding Uber in the past. Two public meetings on the topic of short-term rentals have been scheduled so far by the City and an online survey is still in progress. The two central questions being asked are: "What are your experiences with short-term rentals?" and "What issues should the City consider?" (City of Toronto, Public Meeting, 2017). Closely connected with attempting to gather data through public consultation sessions is the collection of data from complaints, although the number of complaints related to short-term rentals is still unpublished. Data from 311 suggests that complaints that might be connected to Airbnb (i.e. noise, zoning), but descriptions are too vague in publically available data to obtain information on the type and volumes of complaints.

\section{Creating Enforceable Policies}

When asked about how to go about regulating phenomena introduced by digital platforms, staff brought up the need to create policies that would actually be enforceable and to "develop regulation through the lens of enforcement." In the case of short-term rentals, they found issue with attempting to impose restrictions like a cap on the number of nights a unit could be booked because this would be impossible to enforce. Even if a digital platform provider like Airbnb was willing to assist the municipality with enforcement, if a resident reached a cap of 180 
nights through one digital provider there would be nothing preventing him/her from listing through another. Keeping track of how many nights a year each unit had been rented would become an impossible task, and therefore other regulatory frameworks might be preferable.

Regulators instead have opted thus far to concentrate on four focus areas related to the development of short-term rental policies: neighbourhood impacts, taxation, housing, and economic development and tourism. As mentioned previously, sufficient data is critical to being able to develop recommendations on the basis of these areas and the types of data that can be collected will likely inform how the platform becomes regulated in the future. Rather than trying to impose restrictions upon all short-term rental providers, the City is more likely to target specific individuals who are abusing the short-term rental system, perhaps by providing large numbers of units on the platform, listing spaces that violate Building or Fire Safety Codes, or perhaps those that are specific types of properties like condos or properties that are rented rather than owned.

\section{Discussion}

What is clear from these discussions with municipal staff is that data collection is at the heart of developing more dynamic regulations that can respond and adapt to technological change. Cities need to have the infrastructure, knowledge, and legal parametres in place to standardized more effective methods of acquiring data. The current Information and Technology division of the City of Toronto is focused largely on the internal development and management of the City's information technology systems, including the management of the City website, services like 311 Toronto and recreation programs, as well as their internal network and technological needs. Yet, perhaps a new need is emerging for an externally focused branch of 
the IT department, which might be able to become active in data collection, the management of data sharing agreements, and a department which might be able to study the broad ways in which new technologies are impacting cities. Initiatives in this type of department might also include considerations surrounding who has access to technology and reliable internet connections and even find ways to support more equal opportunities for internet access through the creation of more City-funded wireless hotspots throughout Toronto. Without the development of a municipal body overseeing technological activity and change, the City will likely continue to struggle to regulate digital platforms and new technologies in piecemeal fashion.

There is also a question embedded in these interviews about how municipalities might advocate for more and better access to data and whether or not there is a role in this discussion for higher levels of government. Whereas right now each municipality must negotiate with digital platform providers for access to data after the platform is already established within the city, it is possible that either the provincial or federal government might be able establish more standardized methods of data collection in the same way that they collect census or financial information. One interviewee mentioned that the intervention of higher levels of government in the collection of data is not unprecedented in the housing market, as the Municipal Property Assessment Corporation (MPAC) obtained legislated rights to access data about property sales through the Assessment Act. Although this agreement does not grant access to the Municipal Listing Service (MLS) database, it did require all sales and transfer data to be registered with the Land Registry Office so that it might be accessible to provincial property assessors. It is possible that similar legislative interventions might assist municipalities in negotiating with digital platform providers for a more formal system of the transfer and collection of data. 


\section{Conclusions}

As digital cities develop and technologies continue to create new avenues for social and commercial interaction, it is imperative that municipalities become better equipped to deal with technological change. Policies need to be set in place that recognize the fact that cities are no longer simply physical structures, but also complex digital networks that require municipal direction and oversight in both spheres. It is impossible to regulate or plan for a digital city solely through traditional means - too many practices and phenomena remain invisible at street-level and citizens increasingly expect their governments to interact with them through technological channels. Until municipalities are able to establish more standardized practices surrounding the regulation of digital platforms, they will always be at a disadvantage in terms of understanding the impacts that technology is having on their cities and in producing regulations that can adequately cope with the scale and pace at which change occurs.

In the case of short-term rentals, the utilization of scraped data reveals the extent to which the practice permeates Toronto and provides longitudinal data reflecting the extent and growth of listings through digital platforms like Airbnb. Without this data, which is currently collected and published by independent researchers or else by hiring private contractors, municipalities must rely on companies like Airbnb to release proprietary data as the City requires it. Yet, relationships between municipalities and digital platform providers are tenuous and rely on good will between the two parties. If a company were to refuse to provide data, there is little that municipalities could do to obtain statistics about digital activities or to enforce regulations that ban certain practices. In short, municipalities require more tools to plan and regulate digital activities within their municipalities and to study the broad impacts these technologies have on residents. 


\section{References}

Airbnb. (2017). Airbnb's Nondiscrimination Policy: Our Commitment to Inclusion and Respect. Retrieved from https://www.airbnb.ca/help/article/1405/airbnb-s-nondiscrimination-policy-our-commitment-to-inclusion-and-respect

Airbnb. (2017). Overview of the Airbnb Community in Vancouver. Retrieved from https://www.airbnbcitizen.com/data/

Airbnb. (2017). Terms of Service. Retrieved from https://www.airbnb.ca/terms?locale=en

Airbnb. (2016). Policy Tool Chest. Retrieved from https://www.airbnbcitizen.com/wpcontent/uploads/2016/12/National PublicPolicyTool-ChestReport-v3.pdf

Airbnb. (2016). Airbnb, Housing, and the City of Toronto. Retrieved from https:/www.airbnbaction.com/wp-content/uploads/2016/10/TorontoHousing2016.pdf

Benner, K. (2017). Airbnb's Super Bowl Ad, Implied Criticism of Trump's Travel Ban. The New York Times. Retrieved from https://www.nytimes.com/2017/02/05/technology/airbnb-super-bowl-ad-trump-travelban.html? $\mathrm{r}=0$

Canadian Mortgage and Housing Company. (2017). Methodology for Rental Market Survey. Housing Market Information Portal. Retrieved from https://www03.cmhcschl.gc.ca/hmip-pimh/en/TableMapChart/RmsMethodology

Castells, M. (2010). Globalisation, networking, urbanisation: Reflections on the spatial dynamics of the information age. Urban Studies, 47(13): 2737-2745.

Castells, M. (2001). Space of Flows, Space of Places: Materials for a Theory of Urbanism in the Information Age.

Century 21 Canada v. Rogers Communication. (2011). BCSC 1196 (CanLII). Retrieved from https://www.canlii.org/en/bc/bcsc/doc/2011/2011bcsc1196/2011bcsc1196.html

City of Chicago. (2016). Ordinance. Amendment of Municipal Code Titles 3, 4 and 17 Concerning Regulation of Hotel Accommodations, Short Term Residential Rental Intermediaries and Shared Housing Units. Retrieved from https://chicago.legistar.com/LegislationDetail.aspx?ID=2549132\&GUID=767B5ED1C79E-4A31-B7A2-EC2B4C3D5890\&Options $=\&$ Search $=$ 
City of San Francisco, Planning Department. (2016). Office of Short-Term Rental Registry and

FAQs. Retrieved from http://sf-planning.org/office-short-term-rental-registry-faqs

City of San Francisco. (2014). Ordinance No. 218-14, Amending Regulation of Short-Term Residential Rentals and Establishing Fee. Retrieved from http://www.sfbos.org/ftp/uploadedfiles/bdsupvrs/ordinances14/o0218-14.pdf

City of Toronto. (2017). 2016 CMHC Average Market Rents (AMR) for Apartments. Retrieved from

http://www1.toronto.ca/wps/portal/contentonly?vgnextoid=d2929a0e20b24510 VgnVCM1 0000071d60f89RCRD\&vgnextchannel=cf1fab2cedfb0410VgnVCM10000071d60f89RCR $\underline{\mathrm{D}}$

City of Toronto. (2017). Short-Term Rentals in Toronto - Public Meeting-March 28 and April 12, 2017. Retrieved from http://www1.toronto.ca/wps/portal/contentonly?vgnextoid=563129a934b1b510VgnVCM1 0000071d60f89RCRD\&vgnextchannel=deb7415ca6b69510VgnVCM10000071d60f89RC RD

City of Toronto. (2016, Jan. 28). Regulating Temporary Accommodation Rentals. Retrieved from http://app.toronto.ca/tmmis/viewAgendaItemHistory.do?item=2016.EX11.19

Dhillon, S. (2016). Cities Take Aim at Airbnb. Globe and Mail. Retrieved from http://www.theglobeandmail.com/news/british-columbia/concerns-about-airbnb-impacton-rentersspread/article30845642/

Dillahunt, T., \& Malone, A. (2015). The Promise of the Sharing Economy among Disadvantaged Communities. CHI '15 Proceedings of the $33^{\text {rd }}$ Annual ACM Conference on Human Factors in Computing Systems, 2285-2294.

Edelman, B., \& Luca, M. (2014). Digital discrimination: The case of Airbnb.com. Harvard Business School Work Paper, 14-054: 1-21.

Edelman, B., Luca, M., \& Svirsky, D. (2016). Racial Discrimination in the Sharing Economy: Evidence from a Field Experiment. American Economic Journal: Applied Economics (forthcoming). Retrieved from http://www.benedelman.org/publications/airbnb-guestdiscrimination-2016-09-16.pdf

Fidalgo, A. (ed.). (2016). The Impact of Airbnb on Housing and Planning. Retrieved from http://www.ifhp.org/sites/default/files/staff/airbnb one - print version.pdf

Gallagher, B. (2012). CouchSurfing Raises \$15 Million Series B from General Catalyst 
Partners. TechCrunch. Retrieved from https://techcrunch.com/2012/08/22/couchsurfingraises-15-million-series-b-from-general-catalyst-partners-others/

Google. (2017). Googlebot. Retrieved from

https://support.google.com/webmasters/answer/182072?hl=en

Gray, J., \& Lämmerhirt, D. (2017). Data and the City. How Can Public Data Infrastructures Change Lives in Urban Regions? Retrieved from https://blog.okfn.org/files/2017/02/DataandtheCity.pdf

Greater Toronto Hotel Association. (2016). Illegal Hotel Rooms. Retrieved from http://www.gtha.com/GovernmentRelations/IllegalHotelRooms.aspx

Gumbs, Q., Dodds, R., \& Griffin, T. (2016). The Secret under the Sheets. The Truth Behind your Next Booking with Airbnb. Retrieved from http://www.ryerson.ca/content/dam/tedrogersschool/htm/documents/ResearchInstitute/Airb nb\%20Report.pdf

Guttentag, D. (2015). Airbnb: Disruptive Innovation and the Rise of an Informal Tourism Accommodation Sector. Current Issues in Tourism, 18(12): 1192-1217.

Interian, J. (2016). Up in the air: Harmonizing the sharing economy through Airbnb regulations. Boston College International and Comparative Law Review, 39(129): 129-161.

Jamasi, Z., \& Hennessy, T. (2016). Nobody's Business: Airbnb in Toronto. Canadian Centre for Policy Alternatives. Retrieved from https://www.policyalternatives.ca/sites/default/files/uploads/publications/Ontario\%200ffic e/2016/09/CCPA\%20ON\%20Nobodys\%20Business\%20FINAL\%203.pdf

Janowski, T. (2015). Digital government evolution: From transformation to contextualization. Government Information Quarterly, 32(2015): 221-236.

Johal, S., \& Zon, N. (2015). Policymaking for the Sharing Economy: Beyond Whack-a-Mole. Retrieved from https://mowatcentre.ca/wpcontent/uploads/publications/106 policymaking for the sharing economy.pdf

KPMG. (2016). City of Toronto Revenue Options Study. Retrieved from http://www.toronto.ca/legdocs/mmis/2016/ex/bgrd/backgroundfile-94513.pdf

MaRS Solutions Lab. (2016). Shifting Perspectives. Redesigning Regulation for the Sharing Economy. Retrieved from https://www.marsdd.com/wp-content/uploads/2016/03/MSLSharing-Economy-Public-Design-Report.pdf 
Melchiorre, A., Woods, J., \& Florin, A. (2016). Legal Considerations for Online Rentals in the Airbnb Age. Retrieved from http://admin.1rmm.com/CMS/Media/2914 41 enCA 0 Legal considerations for online rentals in the Airbnb age.pdf

Ministry of Tourism, Culture, and Sport. (2016). Information Overview of Destination Marketing Programs in Ontario Considerations for Tourism Organizations. Retrieved from http://www.mtc.gov.on.ca/en/invest/destination marketing.shtml

Mossberger, K., Tobert, C., \& Franko, W. (2013). Digital Cities: The Internet and the Geography of Opportunity. Oxford: Oxford University Press.

Motala, M. (2016). The 'taxi cab problem' revisited: Law and Ubernomics in the Sharing Economy. Banking and Finance Law Review, 31(3): 467-511.

Mukhija, V., \& Loukaitou-Sideris, A. (2014). The Informal American City. Cambridge, MA: MIT Press.

Nellen, A. (2015). Taxation and today's digital economy. Journal of Tax Practice and Procedure, 17(2): 17-26.

Powell, B. (2016). John Tory Set to Back Tax on Hotels, Short-Term Rentals. The Toronto Star. Retrieved from https:/www.thestar.com/news/city hall/2016/11/23/john-tory-set-toback-tax-on-hotels-short-term-rentals.html

Quebec. (2016). Regulation Respecting Tourist Accommodation Establishment, E-14.2, r.1. Retrieved from http://legisquebec.gouv.qc.ca/en/pdf/cr/E-14.2,\%20R.\%201.pdf

Quebec. (2015). Bill 67: An Act mainly to improve the regulation of tourist accommodation and to define a new system of governance as regards international promotion. Retrieved from http://www.assnat.qc.ca/en/travaux-parlementaires/projets-loi/projet-loi-67-41-1.html

Rauch, D. E., \& Schleicher, D. (2016). Like Uber, but for local governmental policy: The future of local regulation of the "Sharing Economy". George Mason University Law and Economics Research Paper Series, 15-01: 1-61.

Revenu Quebec. (2016). Changes to the Tax on Lodging Effective November 1, 2016. Retrieved from http://www.revenuquebec.ca/en/entreprises/taxes/hebergement/modifications1nov2016.asp $\underline{\mathrm{X}}$

Robinson, L., et al. (2015). Digital inequalities and why they matter. Information, 
Communication \& Society, 18(5): 569-582.

Robinson, P., \& Johnson, A. (2016). Civic hackathons: New terrain for local government-citizen interaction? Urban Planning, 1(2): 65-74.

Roy, A. (2005). Urban informality: Toward an epistemology of planning. Journal of the American Planning Association, 71(2): 147-158.

Schneiderman, E.T. (2014). Airbnb in the City. Retrieved from https://ag.ny.gov/pdfs/AIRBNB\%20REPORT.pdf

Shoup, D. (2014). Informal parking markets: Turning problems into solutions. The Informal American City. Cambridge, MA: MIT Press.

Ted Rogers School of Management. (2016). Airbnb \& the Impact on the Canadian Hotel Industry. Retrieved from http://www.ryerson.ca/content/dam/tedrogersschool/htm/documents/ResearchInstitute/CD N Airbnb Market Report.pdf

Urban Metrics. (2017). Toronto Economic Impact Statement. Retrieved from https://www.airbnbcitizen.com/wp-content/uploads/2017/02/airbnb-Economic-Impact$\underline{\text { Statement-Toronto-Final-released.pdf }}$

van der Heijden, J. (2010). Privatisation of building code enforcement: a comparative study of regimes in Australia and Canada. International Journal of Law in the Built Environment, 2(1): 60-75.

Wegmann, J. (2014). "We Just Built It": Code Enforcement, Local Politics, and the Informal Housing Market in Southeast Los Angeles County. Dissertation, City and Regional Planning at University of California, Berkeley. 